\title{
Beszámoló a Fonyód 150 éves présház (homokbánya) és a Sándor utca 26. területén folytatott 10-11. századi temetök sírjainak leletmentéséröl
}

\author{
MAGYAR KÁLMÁN
}

e-mail: magyarkalman@digikabel.hu

\begin{abstract}
MAGYAR, K.: Report on excavations of cemeteries from the 10-11th century centered in Fonyód, near the 150 years-old press-house and at Sándor str. 26.

Abstract: This article deals with excavations made in Fonyód between 1996-1998 and in 2001, where we located 10 and 11 th century old cemeteries. The first excavation was centered by the sandpit near the 150 year-old press house. Due to numerous field works lasted for decades, a large group of burials were almost completely destroyed. We were able to determinate its age and characteristics from the skeleton remains and funeral offerings of one grave (S-terminalled lockrings). During our other excavation made on a small dune at Sándor street 26 , we found a similar cemetary from the 10-11th century with 54 graves and burial remains. Based on the pottery findings, it was in use by the Romans and later became the funeral site of the early inhabitants of Fonyód. The early Arpadian cemetary was located on the west side of the mound. The graves were situated westward-eastward mostly without funeral offerings, but in nine cases we recovered notable findigs like bronze S-terminalled lockrings, shell necklaces and bronze rings on the annulary bones. We could not find any coffins or traces of bricks in the recovered area. There were many instances of skeleton remains of adolescent or small children beside the adult skeletons - mostly female - which indicate family burials. Furthermore, we recovered skeletons positioned with both arms across the waist. Towards the west, a five meter wide empty tract occured to us where a jar and two kinds of animal bones surfaced - one of a dog and the other possibly of a boar. Considering there were no other findings in that area, it might have been a significant place for burial customs or further ceremonial rituals.
\end{abstract}

Keywords: Fonyód, sandpit, Sándor street 26, excavations, early Arpadian age, cemetaries from the 10-11th century, common burials, family burials, graves, funeral offerings, jewels, ornaments, animal bones, burial customs.

\section{Bevezetés}

Az 1985-ben megjelent Fonyód története régészeti összefoglalójában még nem szerepeltek a 150 éves présház melletti homokbányában, illetőleg a Sándor utca 26. számú telken később megtalált 10-11. századi temetők anyagai. ${ }^{1}$ (1-29. ábra) Ezek a temetők ugyanis még 1993-ban is ismeretlenek voltak a kutatók számára. ${ }^{2}$ Csupán 1996-ban szerezhettünk először tudomást az ún. 150 éves présház melletti homokbányában a

1 MAGYAR Kálmán: Fonyód története az őskortól a középkorig. Fonyód története (szerk. KANYAR József), Kaposvár, 1985, 23-104. (Továbbiakban: MAGYAR 1985.)

2 MAGYAR Kálmán: A honfoglalás és az Árpád-kor régészeti emlékei... Nemzeti Történelmünk I. Jubileumi kötet, Kaposvár, 1993, 3-181. (Továbbiakban: MAGYAR 1993.) bányászás során előkerült temető sírjairól. ${ }^{3}$ (2-8. ábra) Ekkor ezen a területen a Balaton Mgtsz (Ordacsehi) a helyi önkormányzat megbízásából telekkialakítást folytatott. Az ő tereprendezésük során az említett Mgtsz emberei gépeikkel csontokat, csontvázakat találtak. A bejelentést követően előbb telefonon, majd személyesen is leállítottam a munkákat. A gépi munka leállítása után történő többszöri kiszállásom és leletmentésem során viszont rögtön kiderült, hogy ezen a 7014 hrsz-ú ingatlan területen már előzőleg is rendszeresen homokbányászást folytattak. Már azelőtt is tudták néhányan, hogy a legalább százötven évvel ezelőtt ideépített présház munkálataikor is nagyon sok sírt találtak. Többen hallottak arról is, hogy a NyK-i domboldalban, föképpen a szőlőműveléstől mentes területén már régebben találtak csontvázakat. Vagyis már jóval előbb megtalálták az általunk először csak 1996-ban azonosított 10-11. századi temető sírjait. (3. ábra) Ezért mi itt azonnal, már 1996. június 13-án elkezdtünk egy leletmentő ásatást akkori munkatársammal, dr. Aradi Csillával közösen. Sajnos már az egynapos munkánk során szembesülhettünk azzal a szomorú ténnyel, hogy a csak most bejelentett gépi dózerolás az eddig még érintetlen temetőrész összes sírját - pár kivételével - teljesen megsemmisítette. Ekkorra az itteni temetkezésekből csupán a bányagödör ÉK-i peremén találtunk meg néhány sírnyomot. Ezeknek a feltárása során alig pár embercsont került elő, többnyire az 1-6. sír szórvány leleteivel együtt. ${ }^{4}$ (6-7. ábra) Az ún. 150 éves présház környékén és az önkormányzat régi szőlője területén - az általam ott 1997-től 1998 végéig folytatott kutatások után - így már csak azt állapíthattam meg, hogy az egykor itt lévő, a 10-11. századi köznépi temető addigra teljesen megsemmisült. $A z$ általunk megtalált hat sír maradványa kivételével a különböző időkben itt végzett földmunkák során teljes egészében elhordták. ${ }^{5}$

2000-ig a másik 10-11. századi temetőröl sem volt tudomásunk, ami Fonyód ÉK-i dombján, a Sándor utca 26. környékén helyezkedett el. (2., 9-11. ábra) Völler Zoltán, a Fonyton Kft. (Fonyód, Harmatos utca 56.) építési megbízottja 2000. november 27-én jelentette be először a kaposvári múzeumnak, hogy az általa irányí-

3 Garay Imre és leánya, Ihászné Garay Tünde (Fonyód, Lenke utca 17.) tettek bejelentést a kaposvári Múzeumnak.

4 Ld. Ásatási Jelentés és Napló, 1996-1998. Rippl-Rónai Múzeum Régészeti Adattára Ltsz.2734. (Továbbiakban: RRM Rég. Adattár Ltsz.2734. Ásatási Jelentés és Napló 1996, 1998.)

5 7014-7014/A.7015/1.,valamint a 7013/1.hrsz., városi önkormányzat. 1:10 000-es katonai térkép 603-331.sz. területein már nem kerültek elő további sírmaradványok. 
tott telekkialakítási földmunkák során a Fonyód Sándor utca 26. számú volt ÁFÉSZ telken „régészeti leleteknek tűnő anyagok" kerültek elő. ${ }^{6}$ A munkák helyszínen történő leállítása után, 2001. április második felében került sor a belterületi 7502/2. hrsz.-ú domboldal általam vezetett régészeti kutatására. ${ }^{7}$ Már az első helyszínelésem során megláthattam a $35 \times 30$ m-es kiterjedésü és a ledózerolás utáni, 5-6 m magas, agyagos domboldalon - a fél méter vastag, bozótos-humuszos talaj alatti agyagban - a Ny-K-i irányban fekvő csontvázak maradványait. ${ }^{8}$ (9., 10-11. ábra )

Ennek nyomán kerülhetett elő itt a 2001. április 23. és május 31 . között végzett régészeti kutatásom során az eredetileg nagy kiterjedésű, 10-11. századi köznépi vagy inkább falusi jellegű temető 54 sírja. ${ }^{9}$ (9-11. ábra)

\section{A 150 éves présház körüli 10-11. századi temető sírjai (1-6.) és leírása (3., 6-8. ábra) ${ }^{10}$}

A homokbányászástól megkímélt ÉK-i padmalyon a már látható sírnyomok felett nyitott $5 \times 5$ m-es szelvényben, $88 \mathrm{~cm}$-es mélységben először az 1. számú sír került elő. Ennek csupán a koponyától derékig tartó már bolygatott részei maradtak meg. Hiányoztak viszont itt is a bordák, illetőleg a bal alkar csontjai. A 3. számú sír ugyancsak bolygatottan került elő. Ennél a mellkas és a gerinc, a bal alkar, a lábszár és a láb csontjai teljesen hiányoztak. A 2., 4. és 6 . sírokból csupán a koponyamaradványok maradtak meg . Az 1. számú sírral függőleges irányban - szórványkövekkel körülvéve - másodlagos helyzetben találtuk meg az 5. számú sír koponyáját. A koponya alatti két karcsont és az előttük fekvő bordacsontok egy női sírra utaltak. A koponya két oldalán egy-egy kisméretü bronz $\mathrm{S}$ végü hajkarika, illetőleg egy nagyobb bronz $\mathrm{S}$ végű hajkarika került elő. ${ }^{11}$ (6-8. ábra)

A 7014. helyrajzi számon fekvő domboldal további temetőrészeit már a 150 éves présház körül folytatott különböző tereprendezések során szintén teljesen

6 MAGYAR Kálmán 2000. december 5-én készült útijelentése és feljegyzése. RRM Rég. Adattára.

7 Ld. Ásatási Dokumentáció, RRM Rég. Adattára 1683., külön Ásatási Jelentés és Ásatási Napló, 2001.Itt az ásatást felmérő geodéták Tóth Ferencként és Lukács Attilaként tévesen szerepelnek.

8 Külön szerencse volt az, hogy a telek abban az időben történő közművesítése során először csak a humuszolást végezték el.

9 Munkám számtalan önzetlen segítője közül ki kell emelnem - az akkori Önkormányzat vezetői mellett - a Városszépítő Egyesület embereit, kiváltképp Csutorás László elnököt és Garay Imrét; A Fonyódért Egyesület, a Julius Meinl, a Fábián Pékség, illetve a DRV képviselőit; a Magyar Bálint Általános Iskola igazgatóját, Szőcs Mihályt és az Ipari Iskola, Postaforgalmi Szakközépiskola és a Gimnázium vezetőit, illetve azok tanulóit; a Balaton Áruház igazgatóját; a jelenlegi polgármestert, Hidvégi Józsefet; Ordacsehi polgármesterét, Kiss Miklóst; a helyi Könyvtár és Művelődési Szervezetek dolgozóit; a területen mellettem földmérőként is sokat segítő Németh Jánost, valamint a Sándor utcai temető sírjait felmérő Geototh Bt. munkatársait. A beszámolóm szerkesztésében végzett munkáért és az angol szövegért köszönetet mondok Magyar Máté irodalomtörténésznek, illetve a grafikák, fotók elkészítéséért M. Hrotkó Zsuzsanna régészeti rajzolónak.

10 1996. november 27-én ideiglenesen védetté nyilvánítottuk a 150 éves présház környéki homokbánya még megmaradt területét. Civil forrásokból még megtudtuk azt, hogy az ordacsehi Mgtsz a hivatalos munkaleállítás után is folytatta az ún. telekkialakításokat.

11 Ltsz. RRM 58.8.1-8.2-8.3. elplanírozták. Ez az elegyengetett rész folytatódott DK-i irányban lefelé a Lenke, illetőleg az Arany János utca irányában is. ${ }^{12} \mathrm{~A}$ présház felett húzódó meredek domboldal Lenke utcával párhuzamos szakaszát az L alakú, 1-7. számú kutatóárkokkal átkutattuk. (3-5. ábra) Megállapíthattuk, hogy a temető ÉNy-i irányban tovább már biztosan nem folytatódott. ${ }^{13}$

A Sándor utca 26. belterület 7502/2. hrsz.-on lévő, 10-11. századi bolygatott temető csontvázmaradványainak a leírása (9-11. ábra)

$A$ terület $D$-i részén lévő kerítéstöl két méterre K-re kerültek elő az 1. sír lábszárcsontjai, illetőleg 1,5 méterre a 2. sír lábszárcsontjai a hozzájuk tartozó lábujjpercekkel. A csontvázak sávban feküdtek és felettük átlagosan $30 \mathrm{~cm}$ vastag, humusszal kevert agyag volt. ${ }^{14}$

Az alábbiakban közlöm a helyszínen készített sírleírásokat.

1. sír: felnőtt, Ny-K-i tájolású, koponya és lábujjak nélküli, bal kar keresztben.

2. sír: felnőtt, Ny-K-i tájolású, koponya töredékkel, bal lábujj hiányzik, bordacsontok hiányoznak.

3. sír: gyermek, Ny-K-i irányú, koponya nélkül, hosszúcsontok megvannak

4. sír: felnőtt, Ny-K-i tájolású, koponya nélkül, medencétöl lefelé, közelében egy szórvány, római korú zöldmázas kerámia peremdarabja került elő. (25-26. ábra)

5. sír: felnőtt, Ny-K-i tájolású, medencétől felfelé, gerincoszloppal.

6. sír: lábszár.

7. sír: Ny-K-i tájolású, koponyával; bordacsontok, alsó lábszárcsontok hiányzanak.

8. sír: Ny-K-i tájolású, a medencétől lefelé, a lábujjak hiányoznak.

9. sír: Ny-K-i irányú, a koponyától a medencéig, szórványcsontokkal.

10. sír: Ny-K-i, koponyatöredéktöl lefelé, hosszúcsontokkal.

11. sír: Ny-K-i, koponyadarabokból, lábszárcsontokból áll, erősen bolygatott.

12. sír: két összetört karcsont.

13. sír: koponyától lefelé a jobb karcsontot, az elcsúszott bal karcsontot jelenti, a teljes alsó végtag megvan, a jobb felső lábszár kivételével. ${ }^{15}$

14. sír: Ny-K-i tájolású, teljes, koponyával is rendelkezik, a láb- és az ujjpercei is megvannak. ${ }^{16}$

A 14. sír környékén lévő területről, annak koponyájától ÉNy-ra 3 m-rel egy szürkésbarna színű, földbeásott, nyaktól felfelé törött oldallal és talppal rendelkező korsót tártunk fel. (28-29. ábra) A 14. sírtól 4 m-re

12 1997-1998-ban került sor a - föleg gépi erővel folytatott - 1-7. számú, 3 méter széles és 5 méter mély kutatóárkok kiásására.

13 Ez a 10-11. századi temető csupán a 150 éves présház mögötti domb lankásabb DK-i oldalában található. Feltehetően még a közelében, az ún. fácánosi részen kialakított Árpád-kori templom körüli temető előzménye volt.

14 A ledózerolt rész felettük még $40-50 \mathrm{~cm}$ vastag lehetett; kötött, sárga agyag, melyben a sírfoltok nem láthatók.

15 A 11-13. sír az előzőekhez képest $30 \mathrm{~cm}$-rel mélyebben található.

$16180 \mathrm{~cm}$ hosszú, 25-30 cm-rel mélyebben van a többitöl, domboldalban megmaradt felszíntöl, $30 \mathrm{~cm}$-rel mélyebben. 
É-ra egy kutyacsontváz és a csontváz lábától 50-80 cm-rel egy agyaras állat, talán disznó maradványai kerültek elő. ${ }^{17}$

15. sír: a 14. számú sírtól 2 m-re délre, a kerítéstől 1,5-2 m-es távolságban teljes, NyK-i tájolású csontvázat tártunk fel.

M/ellékletes/ 16. sír: Ny-K-i, $165 \mathrm{~cm}$ hosszú, koponya része szétesett $(24 \times 16 \mathrm{~cm})$, kezei összetéve, a csontváz a lábujjakig teljesen megvolt. A koponyája jobb oldalán az alsó állkapocsnál, valamint a baloldaIon a halántéknál egy-egy sima bronzkarika került elő. A jobb kéz gyűrüsujján egy sima bronz karikagyürüt tártunk fel. (12. ábra)

17. sír: lábfej hiányzik, lábcsont töredékes.

18. sír: Ny-K-i, koponya lapított, kezek keresztben fekszenek.

19. sír: Ny-K-i, bolygatott csontok kerültek elő. A 17. sír balján, tőle $5 \mathrm{~cm}$-re és a medencéje közepén feküdt az összetört koponyája, a hosszúcsontok és a csigolyák egymásra rakva.

20. sír: Ny-K-i, koponya és az alsó lábszárak hiányoznak.

21. sír: Ny-K-i tájolású, teljes, a bal kart a medencéjére helyezték, a jobb kar mellette, a 20. sírnál egy ásónyommal mélyebben.

22. sír: lábszárcsontok..

23. sír: koponya nélkül, Ny-K-i tájolású.

24. sír: teljesen ép, csak a koponya törött, Ny-K-i.

25. sír: koponya nélkül, teljes, $\mathrm{Ny}-\mathrm{K}-\mathrm{i}$.

M. 26. sír: Ny-K-i, $127 \mathrm{~cm}$ hosszú, teljes, a felső lábszárig maradt meg, bordája hiányos, medence hiányos, koponyája mellett baloldalt élével felfelé kés, karcsontja mellett szélesebb, lemezből készült bronz karperec. (13., 22., 27. ábra)

27. sír: alsó és felső lábszárcsontok.

28. sír: koponya nélküli, hiányos.

M. 29. sír (a 25. sír felett): a koponyától a felső lábszárig maradt meg, a balkéz behajlítva, keresztben fekszik, koponya két oldalán egy-egy $S$ végü bronz hajkarika. (14., 21-22. ábra)

M. 30. sír: Ny-K-i, koponya és a lábujjak hiányoznak, a koponya helyén nyaklánc gyöngyei: $6 \mathrm{db}$ különböző színü és alakú, gyürüsujjnál bronz karikagyürü, erősen bolygatott, a bolygatás miatt a 31. sírnál talált koponya tartozhatott eredetileg hozzá. (15., 23-24. ábra)

M. 31. sír: teljes vázzal, hiányos, kézujjak és a lábujjak hiányoznak, koponyája helyén $S$ végü hajkarika, a csontváz medencéje alatt $18 \mathrm{db}$ csiga feküdt. (Pár darab összetörve! $)^{18}$

M. 31/A sír: a 31. sír csontjaival keveredve, koponyája (?) közelében ezüst, bordázott $S$ végü hajkarika (16., 23-24. ábra)

32. sír: a koponya, a láb- és a kézujjak hiányoznak, a balkar keresztben, enyhén bolygatott állapotban.

17 Itt is lépcsőzetesen feküdtek csontvázak, mint a már említett 14. számú sírnál. A 14. számú sír körül talált szürkésfekete korsót, ill. az agyaras fejü- és kutyacsontokat a feltárásuk után dokumentáltuk és felszedtük. Ezek a restaurálásuk után természettudományos vizsgálatra kerültek.

18 A nagyon erős bolygatás miatt a 31/A sír csontjai nem voltak igazán azonosíthatóak és dokumentálhatóak.
33. sír: koponyája törött, hiányzik a jobb kéz csontja.

34. sír: Ny-K-i, a bal karcsontok szétszórtak.

M. 35. sír: $154 \mathrm{~cm}$ hosszú, törött, hiányos koponyája mellett, két nagy, bronz $S$ végü hajkarika. (17., 23-24. ábra)

36. sír: Ny-K-i tájolású, teljes csontváz, törött, hiányos a koponyája, mindkét karja behajlítva.

37. sír: Ny-K-i tájolású, vékonycsontú gyermek, medencéje hiányzik, a teljes jobb karcsont, míg a balnál az alsó karcsont hiányzik.

M. 38. sír: Ny-K-i tájolású csontváz, a lábujjak hiányoznak, a gyűrűsujjnál bronz karikagyűrű került elő. (18., 23-24. ábra)

39. sír: bal alkar, bal felső és részben alsó lábszár, jobb alsó lábszár.

M. 40. sír: Ny-K-i tájolású, jobb alsó kar, kézujjak és a lábujjak is hiányoznak. Félbetörött koponya jobb oldalán egy-egy kicsi, bronzlemezes $S$ végű hajkarika, baloldalt egy nagyobb, vékony bronzkarika volt. A csontváz felszedésekor törött gyöngyök és egy ép, henger alakú gyöngy is előkerült. (19., 25-26. ábra)

41. sír: koponya félbetörött, a bal alkar és a lábujjak hiányoznak, a jobb kar a medencén keresztben.

M. 42. sír: Ny-K-i tájolású, $156 \mathrm{~cm}$ hosszú, teljes csontváz, koponya törött, a gyürüsujjnál egy bronz karikagyürü. (20., 25-26. ábra)

43. sír: Ny-K-i tájolású, teljes csontváz. Felette került elő a 33. sír (egymásra temetkezés).

44. sír: összedobált lábszárcsontok.

45. sír: összedobált lábszárcsontok.

46. sír: félbetörött koponya.

47. sír: koponyatető.

48. sír: Ny-K-i tájolású, teljes csontváz, bal karja a medencénél keresztben.

49. sír: Ny-K-i tájolású, teljes csontváz, törött, nagyméretü koponya.

50. sír: koponya összetörött, felső karcsontok és a medencétől lefelé megmaradtak a lábszárcsontok, a lábujjak hiányoznak.

51. sír: koponya nélkül, medence és lábszárcsontok.

52. sír: koponya nélkül, medence és lábszárcsontok.

53. sír: bolygatottan és összedobálva került elő.

54. sír: Ny-K-i tájolású, koponyától az alsó lábszárig, bolygatottan és összedobálva került elő. ${ }^{19}$

\section{A temető feltárt sírjainak a rövid jellemzése ${ }^{20}$}

A 2001-es ásatásunk során feltárt temető domboldalában megtalált sírjai egy nagyobb kiterjedésű temető

19 A sírok felmérését a Geototh (Marcali), Tóth János és Lukács Péter földmérők végezték. A négy ponton mért síroknál a térképen külön-külön a mélységadat és a pontos Ny-K-i irány is jelölve lett. A számozott dobozokban összecsomagolt sírok csontjai a Fonyódi Városszépítő Egyesület irodájában kaptak elhelyezést.

20 Költő László és Csapó János a sírok csontvázanyagából a mintákat már 2001-ben - a helyi Városszépítő Egyesülettöl - átvették természettudományos vizsgálat céljából. Ugyanakkor Költő László segítségével a Természettudományi Embertár fiatal kutatói Papp Ildikó vezetésével - ugyancsak vállalták az emberi csontanyag későbbi vizsgálatát. Jelenlegi tudomásunk szerint (Garay Imre 2015. évi közlése) a csontvázanyag még Fonyódon, a helyi Önkormányzat megőrzésében található. 
kilenc sírsorában helyezkedtek el. A kutatás során csak a temető alsó sírsorait találtuk meg. Ezek a dombtetőn egy ásónyomnyira, míg a széleken egy méteres mélységben kerültek elő. A felső agyagos réteget, amelyben további temetkezések lehettek, elhordták, másrészt az erózió a dombtetőről a domb lábához vitte le az ottani, eredetileg magasabb talajt. Rendkívül kemény, sárga agyagban voltak a sírok, de javarészt nem maradtak meg a sírfoltok. Éppen ezért a teraszokra épülő szelvénysorral kutattuk végig a területet. (9. ábra) Legmagasabban az 1. sírsor 1., 2. és 4 . számú sírjait találtuk meg. Relatíve legalacsonyabban pedig talán a domboldal alján megmaradt 9. sírsor 49. számú sírja feküdt.

A 2. sírsor a 3., 9., a 3. sírsor az 5-8., 10. és 13., a 4. sírsor a 11-12., 14-15., és 52., az 5. sírsor a 1619., 21.,20., és az 53. sírokból állnak. A 6. sírsor 2223., 28., 51., 32., 34-35. (30. sír) számú sírjaitól lefelé haladva a 7. sírsor: 27., 33., 42-43., 37., 50. számú és a 8. sírsor: 26., 25., 54. (29. sír), 48., 44., 38-41., 31., 36. számú temetkezései a legszámosabbak.

Egymásra történő temetkezések a D-i részen a 25. és a 29. sír, illetve a $\mathrm{Ny}$-i részen a 33. és a 43. sírok esetében voltak. A 25. sírra a 29. sírt és a 33. sírra a 43. sírt temették rá.

Sajnos a sírsorok legtöbb sírját már az 1970-es évektől folytatott földmunkák során nemcsak megbolygatták, hanem azokat javarészt el is hordták. ${ }^{21}$ Ilyen illegális földmunkák folytak a Sándor utca 26. számú telekkel szembeni, a Mező utcára eső dombtetőn és a lakás domboldalában is. Az önkormányzat által Kardos Attilának és apjának, Kardos Jánosnak eladott Mező utcai telekrészen, 2007. április-májusában, a házalapok kiásása során folytathattam csak régészeti ellenőrzést. Ennek során megállapíthattam, hogy a különböző telekrendezési, házépítési földmunkák már itt is megsemmisítették a Sándor utcából a Mező utcai domboldali részébe átnyúló, igen nagy kiterjedésű temető sírjait. ${ }^{22}$

\section{A megtalált mellékletes sírok leírása és értékelése}

A sírszámozás sorrendjét követve először a 16. sír leírását közöljük. (12., 21-22. ábra) Ebben a jobb kéz gyűrüsujja csontján egy lapított tetejü bronz gyűrü, kétoldalt a koponyánál egy kisebb és egy nagyobb, vágott végű bronz karika volt. ${ }^{23}$

A 26. sírban (13., 21-22. ábra) egy széles, lemezes, bronz karperecet tártunk fel. A koponyánál baloldalt hegyes, keskeny pengéjű kés volt, heggyel felfelé, talán a rontó szellemek ellen. ${ }^{24}$

21 Ezek a sírok - a hivatalos bejelentés nélkül az 1970-es években ideépült - ÁFÉSZ kocsma, majd később a dombtetöre telepített üdülőbódék kialakítása során egyszerüen megsemmisültek.

22 Ld. Ásatási Dokumentáció, Rippl-Rónai Múzeum Régészeti Adattára, 2007. Ltsz. 2557. Hasonló telekrendezési és házépítési munkák miatt végzett ilyen jellegű temetőfeltárást Költő László a Kaposvár-Kertészet, Ezüsthárs lakótelep területén. (HoNTI Szilvia - HAJdú ÁdÁm Dávid - KöLtő László - MolNÁR István - NÉMETH PÉTER Gergely - SIPOs Kármen: Régészeti feltárások Somogy megyében 2007-2011 között. Rippl-Rónai Múzeum Közleményei 1. (szerk. JuHÁsz Magdolna) Kaposvár, 2013, 121-122.)

23 Ltsz. RRM 58.16.1.1., 58.16.1.2-16.1.3.

24 Ltsz. RRM 58.16.2.1., 58.16.2.2.
A 29. (a 25. számúra rátemetett) sír koponyája két oldalán egy-egy kisebb bronz $S$ végü hajkarikát találtunk. ${ }^{25}$ (14., 21-22. ábra)

A 30. sír (15., 23-24. ábra) A kézcsonton bronz karikagyürü, a nyaktájon hat különböző színű és formájú gyöngy mutatkozott: üveg, paszta, hatszög alakú, karika, fehér és fekete, színjátszós. ${ }^{26}$

A 31. és a 31/A. számú (16., 23-24. ábra), egymásba temetett, erősen bolygatott sírok csontvázainál az egyik (31/A) koponyától 30 cm-re DNy-ra, szórványban egy nagy alakú, másfél S-ben végződő, bordázott végü ezüst hajkarika volt. A másik (31.) koponyája helyén $S$ végü bronz hajkarika került elő. A csontok (31.) felszedésekor a bal lábcsontok mellett $18 \mathrm{db}$ hosszúkás, hegyes végű csigaházat találtunk. ${ }^{27}$

A 35. sír (17., 23-24. ábra) egy-egy nagy méretü $S$ végű hajkarikával rendelkezett a koponya két oldalán. ${ }^{28}$

A 38. sír (18., 23-24. ábra) jobb kéz gyürüsujj csontjánál bronz karikagyürü volt. ${ }^{29}$

A 40. sírnál (19., 25-26. ábra), a koponya két oldalán egy-egy kisebb méretű bronz $\mathrm{S}$ végű hajkarika, a nyaktájon a csontok felszedésekor törött gyöngyök, (egy hasáb és egy karika alakú ép), illetve egy bronz karika voltak. ${ }^{30}$

A 42. sírnál (20., 25-26. ábra), a gyűrüsujj csontján bronz karikagyürüt találtunk. ${ }^{31}$

Végső soron kilenc sír csontváza mellett találtunk mellékleteket. A 14. számú sír koponyájától Ny-ra és É-ra is 3 méterre egy földbeásott szürke római korú korsó került elő. ${ }^{32}$ (28-29. ábra) Ásatási területünk D-i szélén, a kerítés melletti kisajátítási mérőkőnél egy nagyobb, piros színű vastag és egy kisebb, vékony, hullámvonalas római kerámia is volt. ${ }^{33}$

A megmaradt temetőrész korát és a temető jellegét elsősorban ezek a mellékletes sírok datálják. (10-20. ábra) A 29., a 35. és a 40. sírban 2-2 S végü hajkarika, a 31., 31/A sírban 1-1 bronz és ezüst, bordázott $S$ végü hajkarika került elő. A 16 . sírban $2 \mathrm{db}$ bronz fülkarika is volt. Ezek ugyanis a 10-11. századi köznépi vagy falusi temetők jellegzetes leletei. ${ }^{34}$ Ugyancsak ezek alapján tarthatjuk ugyancsak erre a korra jellemzőnek a bronz karikagyürűket, amelyek a 16., a 30., 38. és a 40. sírban fekvő halottak gyűrüsujja csontján maradtak meg. A 26. sírban előkerült értékesebbnek tűnő,

25 Ltsz. RRM 58.18.3.1., 58.18.3.2.

26 Ltsz. RRM 58.16.4.1, 58.16.4.2.

27 Ltsz. RRM 58.16.5.1., 58.16.6.1

28 Ltsz. RRM 58.58.16.7.1.

29 Ltsz. RRM 58.16.8.1.

30 Ltsz. RRM 58.16.9.1., 58.16.9.4. A gyöngyök is a 58.16.91. Ltszmal jelöltek.

31 Ltsz. RRM 58.16.10.1

32 A 4. századi korsó töredékes volt és a vállától felfelé eldózerolták.

33 A 4. bolygatott sír közelében egy római mázas peremtöredék is elökerült. Ltsz. RRM 58.16.12.1.

34 SzŐKE BÉLA Miklós - VÁNDOR László: Pusztaszentlászló Árpád-kor temetője Fontes Archeologici Hungariae, Akadémiai Kiadó, Budapest, 1987. 54-59. (Továbbiakban: SzÖKE-VÁNDOR 1987.) Legújabban Kovács László: $A$ Kárpát-medence honfoglalás és kora Árpád-kori szállási és falusi temetői. Kitekintéssel az előzményekre. Vázlat. In: A Honfoglalás kor kutatásának legújabb eredményei: Tanulmányok Kovács László 70. születésnapjára Monográfiák a Szegedi Tudományegyetem Régészeti Tanszékéről 3. (szerk. RÉVÉSz László-WoLF Mária) Szeged, 2013. 511-605. Továbbiakban: Honfoglalás kor kutatásának legújabb eredményei 2013.) 
díszítetlen ezüst karperec is szintén ezeknek az ún. köznépi temetőknek a korra jellemző lelete. Csakúgy, mint a 40. sírban - az ott elökerült két $S$ végü hajkarikán kívül - fellelhető különböző egyszerü gyöngyök. A 30. sírban (ahol a bronz karperec volt!) ugyancsak a nyakláncra utaló, hat darab színpompás gyöngyöt találtunk. Érdekes lelet volt még a 31. és a 31/A. sírokban - az $S$ végű hajkarikákon kívül - előkerült $18 \mathrm{db}$ csigaház is. Különleges lelet lehetett viszont a 26. sír bronz karpereces koponyája mellett, hegyével felfelé elhelyezett kés megmaradt vaspengéje. Talán ez is egyfajta pogány kori rontáselleni népszokásra utalhatott, csakúgy, mint a 14. sír közelében feltárt vaddisznó- és kutyacsontok is. ${ }^{35}$

Az itteni több felnőtt korú, általában női csontváz mellett kisebb, illetve serdülő korú gyermek csontvázmaradványai is voltak. Ezek családi temetkezések lehettek. Több sírnál mind a két kart, vagy helyenként csak az egyiket a deréknál keresztben helyezték el. ${ }^{36}$

Végső soron úgy tűnik, hogy az egyszerübb mellékletekkel rendelkező, bolygatott és részben kirabolt itteni sírokba egy szegényebb falusi, a régebbi szakirodalom szerint köznépnek nevezett 10-11. századi fonyódi népesség temetkezhetett a Sándor utca 26 . számú telkén, feltehetően már a 10. század első felétől. ${ }^{37}$

\section{Összegzés}

A 150 éves présház környékén lévő homokbányában, 1996-1998 között folytatott leletmentésünk során megállapíthattuk, hogy az 1800-as évek közepétől a napjainkig ott folyó bolygatások, illetőleg homokhordás következtében egy nagyobb létszámú 10-11. századi temető került megsemmisítésre. Az ottani elpusztult temető korát és részben jellegét hat sír csontvázmaradványai, illetőleg a temetkezés (5. sír) bronz $S$ végű hajkarikás mellékletei és a részlegesen megmaradt - koporsót helyettesítő kőpakolások alapján határozhattuk meg. ${ }^{38}$

Hasonló jellegű 10-11. századi temető 54 sírját, illetőleg sírmaradványait sikerült feltárnunk 2001-ben, a 150 éves présház temetőjétől É-ra, kb. két km-re lévő Sándor utca 26. számú telek homokdombján. Ez a domb - az előkerült kerámialeletek alapján - már a római korban is lakott volt. ${ }^{39}$

Ezen rómaiak által is használt, enyhe lejtésű domb tetején és a Ny-i oldalán létesített 10-11. századi sírokba temetkezett Fonyód falu korai népessége. Ennek a temetőnek megtaláltuk a - nagyobb részben

35 A 14. sír környéki sírok üres területéről kerültek elő a kutyacsontváz maradványai, valamint egy szürkésfekete, szájával lefelé beásott korsó maradványai is.

36 Az 1., 16., 18., 21., 32., 36., 41., 48. számú sírok.

37 Honfoglalás kor kutatásának legújabb eredményei 2013, 25-373.

38 Ilyen kőpakolással keretezett kora Árpád-kori sírokat a BodrogAlsóbün, az általunk 1979-ben feltárt templom körüli temetőben figyelhettünk meg. - MAGYAR Kálmán: Szent István államszervezésének régészeti emlékei Kaposvár-Segesd, 2001, 36-38. (Továbbiakban: MAGYAR 2001)

39 A terület a 4. századi szürkésbarna korsó, és a sárgás mázas peremdarab, illetve a terra sigillata-szerü töredékek szerint római kori használatban is volt. Bodrog-Alsóbü kora Árpád-kori birtokközpontja is egy ilyen jelentős római kori előzménnyel rendelkezett. MAGYAR 2001.25-69. melléklet nélkül megmaradt - NyK-i tájolású, sírcsoportjából kilenc egyszerü melléklettel rendelkező sírját. Ezek többsége bronz $S$ végü vagy sima hajkarikával (16., 29., 31., 35., 40. sír), a nőknél gyöngyből vagy kagylóból álló nyaklánccal (30., 40. sír), egynél bronz karpereccel (26. sír), illetőleg a gyürüsujj csontján bronz gyürűvel (16., 38., 42.) rendelkező temetkezések voltak.

A viszonylag ép és nem bolygatott sírok a domb D-i szélén és a Ny-i, az építkezések által alig sértett peremrésznél maradtak meg. ${ }^{40} \mathrm{~A}$ sírok rendkívül kemény, sárga agyagban voltak és a sírfoltok javarészt nem maradtak meg. A sírsorok párhuzamosan húzódtak, bennük a Ny-K-i tájolású sírokkal. Sem koporsót, sem körben kőpakolást vagy téglanyomokat nem találtunk. Több felnőtt korú, de általában női csontváz mellett kisebb vagy serdülő korú gyermek csontvázmaradványai is voltak. Ezek családi temetkezések lehettek. Több sírnál mind a két kart, vagy helyenként csak az egyiket, a deréknál keresztben helyezték el. Pusztaszentlászló korai sírjainál is megfigyelték ezt a szokást. Fiad-Kérpuszta hasonló korú, ún. köznépi temetőjénél is voltak ilyen temetkezések. ${ }^{41}$

Egymásra történő temetkezések is voltak, így a D-i részen a 25. sírra a 29. sírt, míg a $\mathrm{Ny}$-i részen a 33 . sírra a 43. sírt temették rá.

A 14. számú sír koponyájától három méterre Ny-ra és derékszögben hasonló távolságban É-ra egy földbeásott, törött korsó került elő. ${ }^{42} \mathrm{~A}$ korsó közelében, tőle ÉK-re három méterre egy kutyacsontváz, míg a 14. sír lábcsontjától ugyancsak három méterre egy agyaras (vad?) disznócsontváz maradványa volt.

Megfigyelhettük, hogy az 51. sír és a kutyacsontváz vonalában, Ny-K-i irányban és a domb hosszúságában egy öt méter szélességű üres sáv húzódott. Ezen a területen - az említett korsó, a kutya és a vaddisznó csontján kívül - semmilyen lelet nem került a felszínre. Ez a kihagyott terület akár a temető használatához tartozó, ott folyó temetési vagy vallási szertartások színtere is lehetett. ${ }^{43}$

40 Kutatásunk során az alsó sírsorokat találtuk meg a dombtetőn egy ásónyomnyira, míg a széleken egy méteres mélységben. A dombtetőről a felső agyagos réteget az erózió is a a domb lábához hordta le.

41 SZŐKE-VÁNDOR 1987, 49.; MAGYAR 1993, 16.; HEgYI BorbálaVARGA Máté: Somogy megye 10-11. századi temetöinek és sirleleteinek kutatása a kezdetektöl napjainkig. Magyar Régészet Online Magazin 2015.Tél, 2.old. 11.jegyz. Hivatkozás: www. magyarregeszet.hu.

42 Az eredetileg szájával fölfelé beásott korsót vállától fölfelé elvitte a földmunkálatok során a munkagép.

43 N. Nepper Ibolya a püspökladány-eperjesvölgyi temetö 10. századi temetörészének csaknem a mértani közepén talált egy sír nélküli szabad térséget, ahol a "facölöp” (faoszlop, bálványfa) csonkját találta meg. - N. NEPPER Ibolya: Hajdú-Bihar megye 10-11. századi sírleletei 1. rész (Magyarország honfoglalás- és kora-Árpád-kori sírleletei 3. sorozatszerk. KovÁcs László-RÉvÉsz László), Budapest-Debrecen, 2002. 220. 
Fonyód Sándor utcai temetője esetében mindenképpen egy nagyobb létszámú és hosszabb ideig használt temetőröl van szó, amely valószínüleg a teljes dombot betöltötte. ${ }^{44}$ Korai megszüntetése esetleg a Szent István-i állam- és egyházszervezés idején, a tőle pár száz méterre D-i irányban, a mai fácánosi részre települő pannonhalmi bencés egyház- és birtokigazgatási központjához köthető. ${ }^{45}$

44 7502/3, 7503., 7504/2, 7505/1., 7505/2., 7478., 7622/15. hrsz. területen feküdhetett.

45 Már 1093-ból említi oklevél Fonyód bencés prédiumát. A már korábban is itt, a fácánosi részen működő bencés templom körüli temetőjét tárta fel Fitz Jenő. (MAGYAR 1985, 69-71.; MAGYAR Kálmán: A bencés rend középkori egyházainak somogyi forrásai a történeti és régészeti kutatások alapján..Örökség és küldetés. Bencések Magyarországon I. (szerk.. ILLÉs PÁL Attila és JuHÁszLACZIK Albin OSB) Rendtörténeti konferenciák 7/1. Budapest, 2012, 100-102.

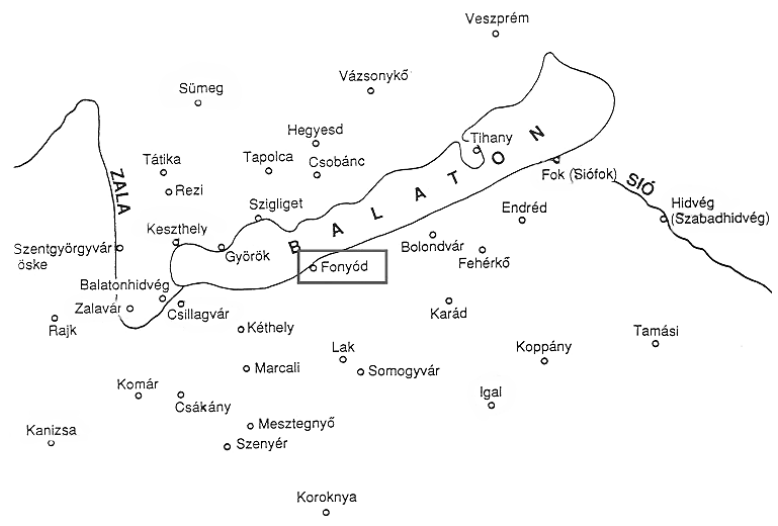

1. ábra. Fonyód a Balaton és környéke térképén (M. Hrotkó Zsuzsanna rajza)

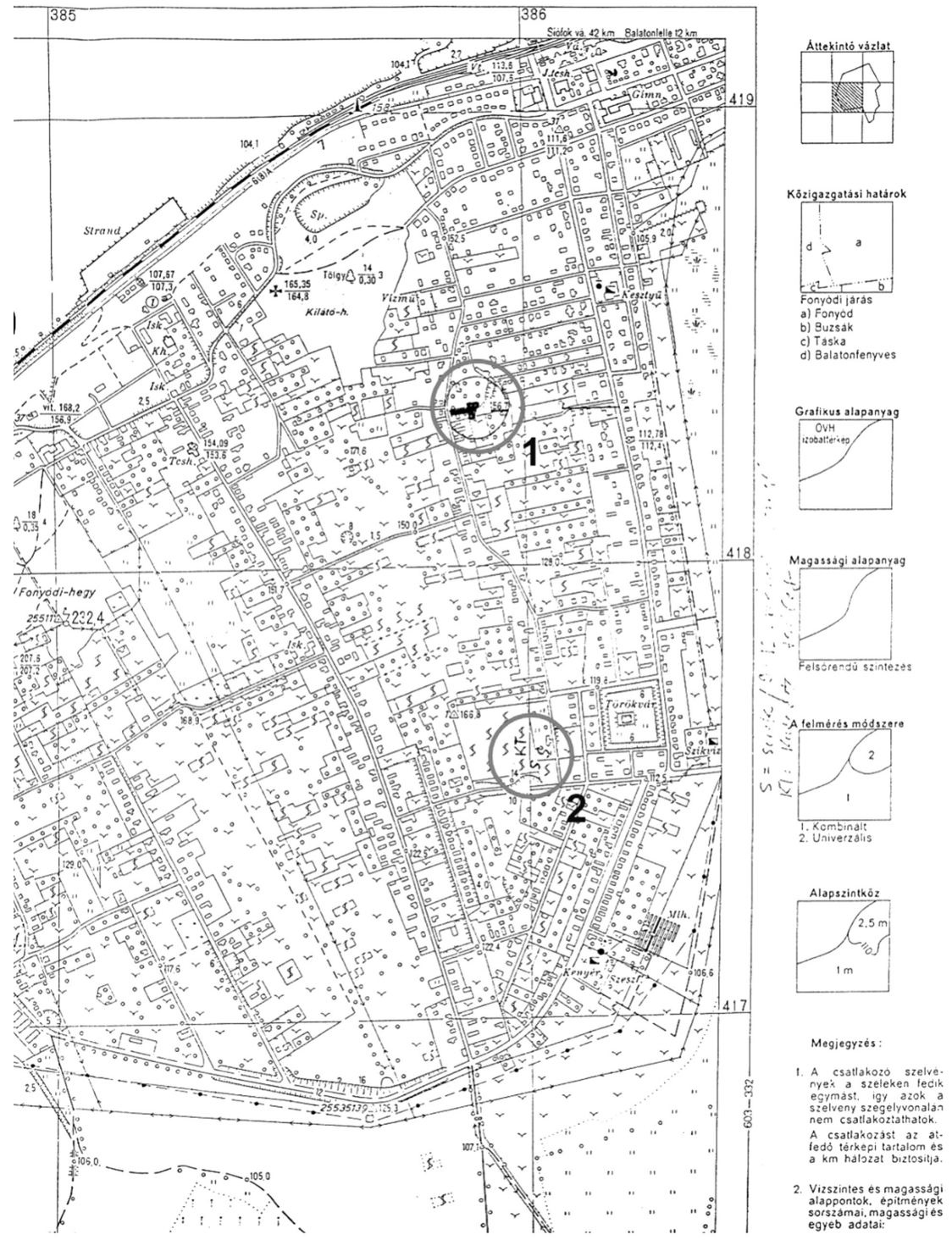

2. ábra. Fonyód 10-11. századi temetői a tízezres léptékü térképen (1.: Sándor u. 26. és a Mező u. sarka, 2.: 150 éves présház és homokbánya) 


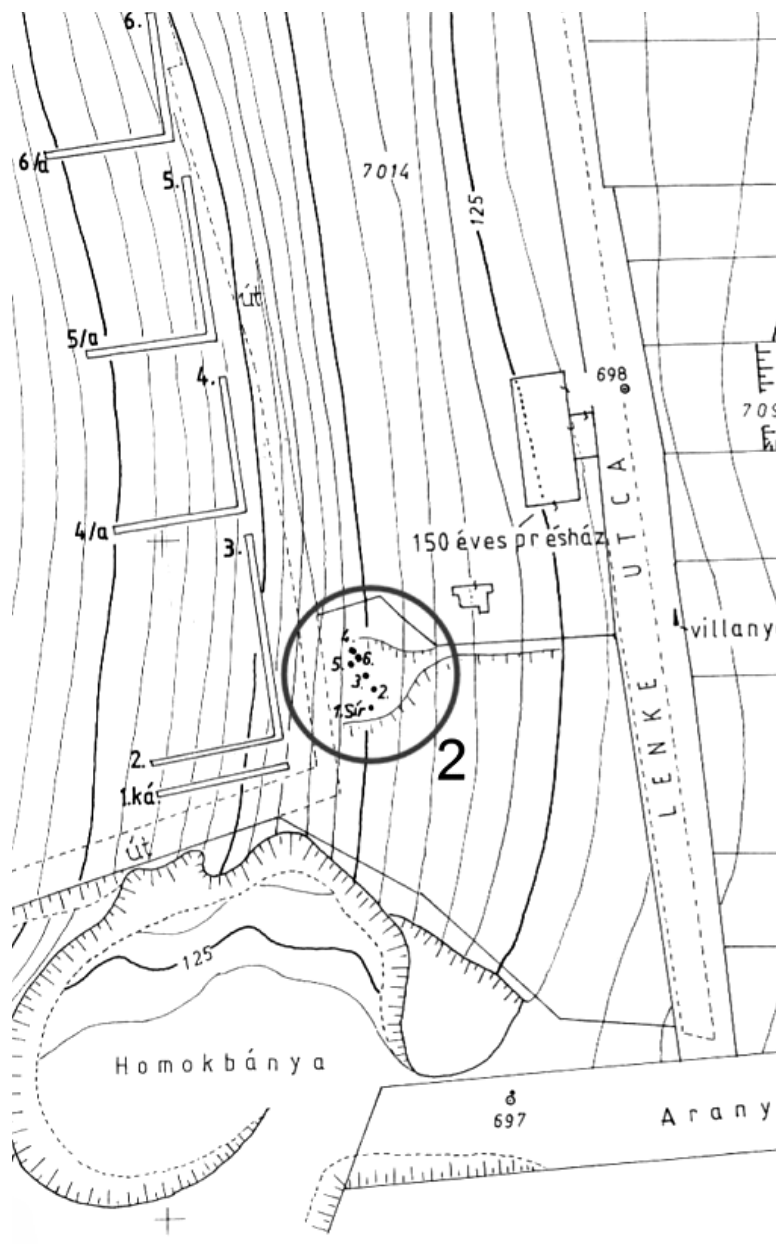

3. ábra. A 150 éves présház melletti homokbányában 1996-ban feltárt, 10-11. századi temető 1-6. sírja (M. Hrotkó Zsuzsanna rajza)

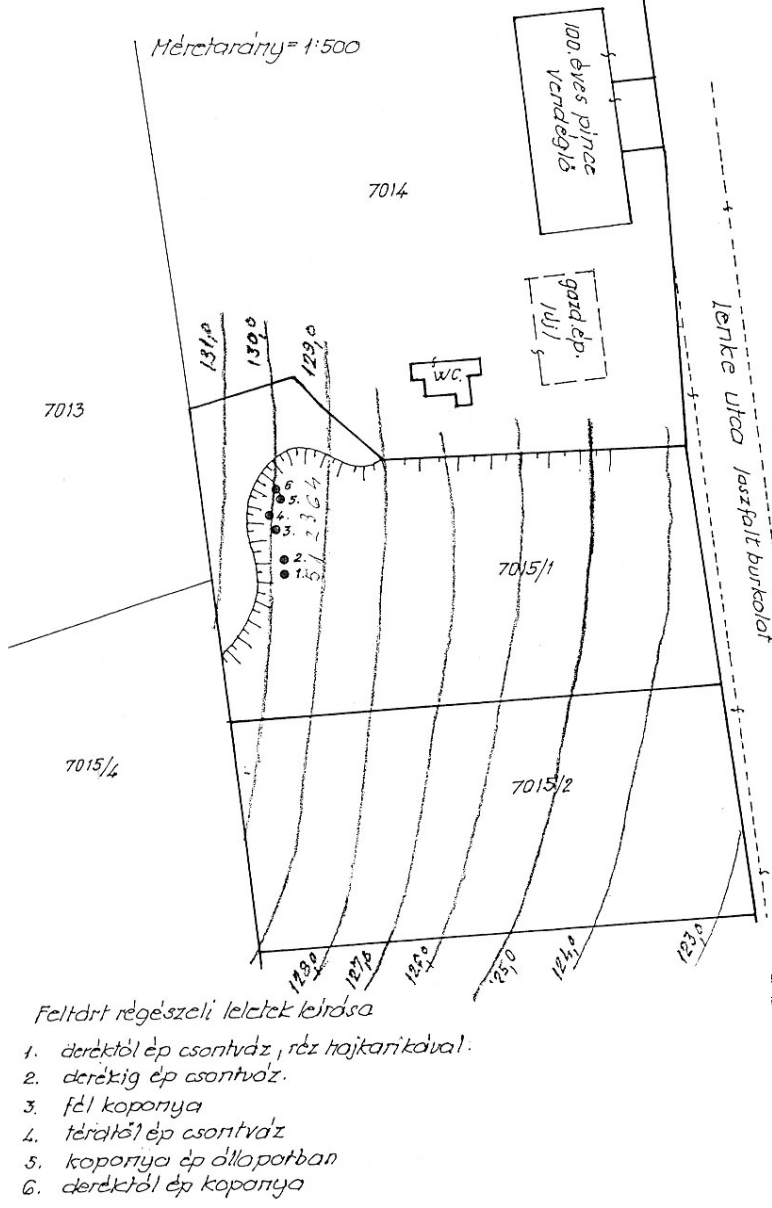

4. ábra. A 150 éves présház melletti temető rétegszintvonalas térképe (Németh János felmérése)

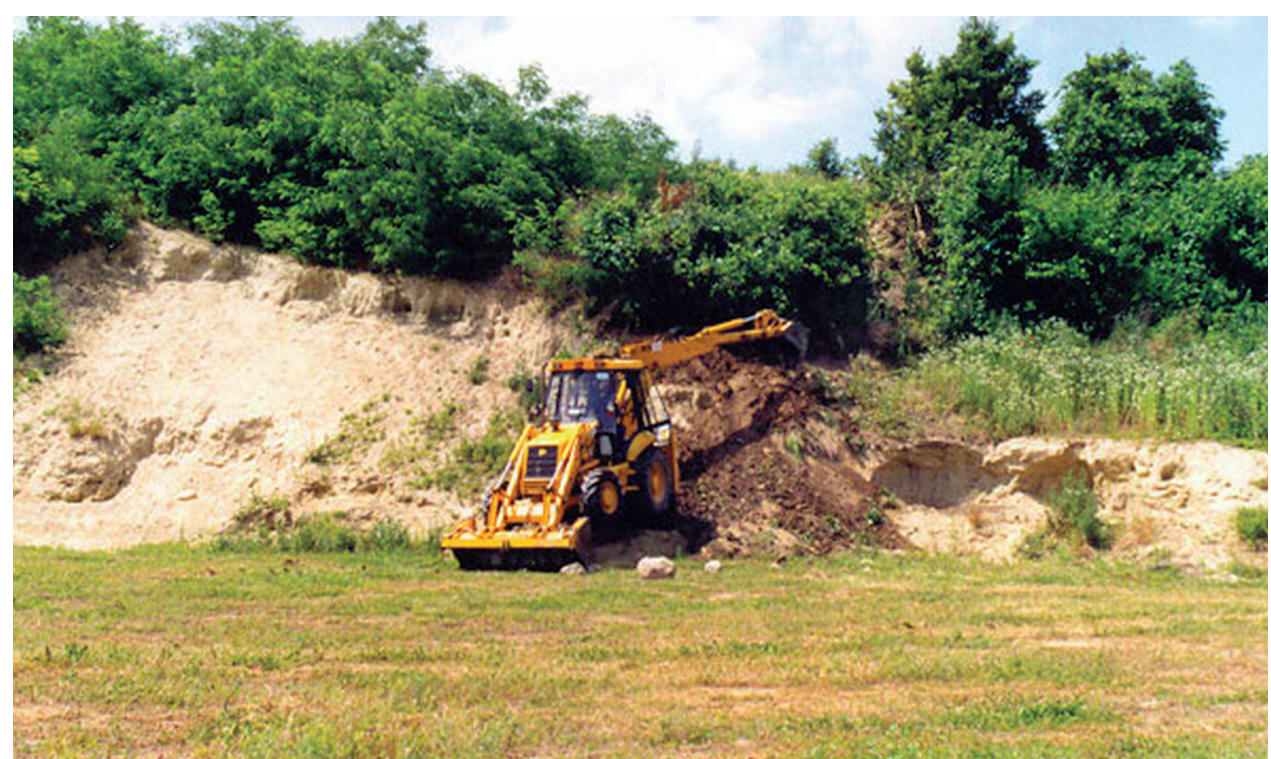

5. ábra. A présház melletti homokbánya megmaradt partfalának kutatása 1997-ben 

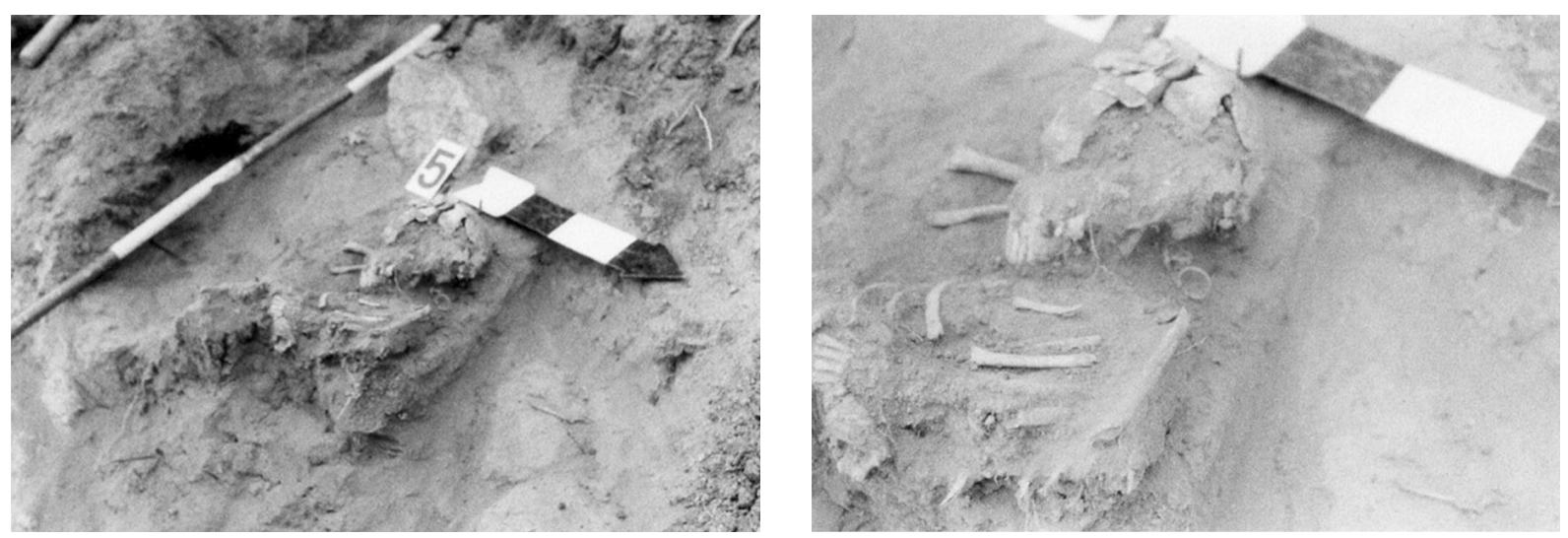

6. ábra. 1996-os feltáráskor megtalált 1-6.sír csontvázmaradványai (Fotó: Dr. Magyar Kálmán)

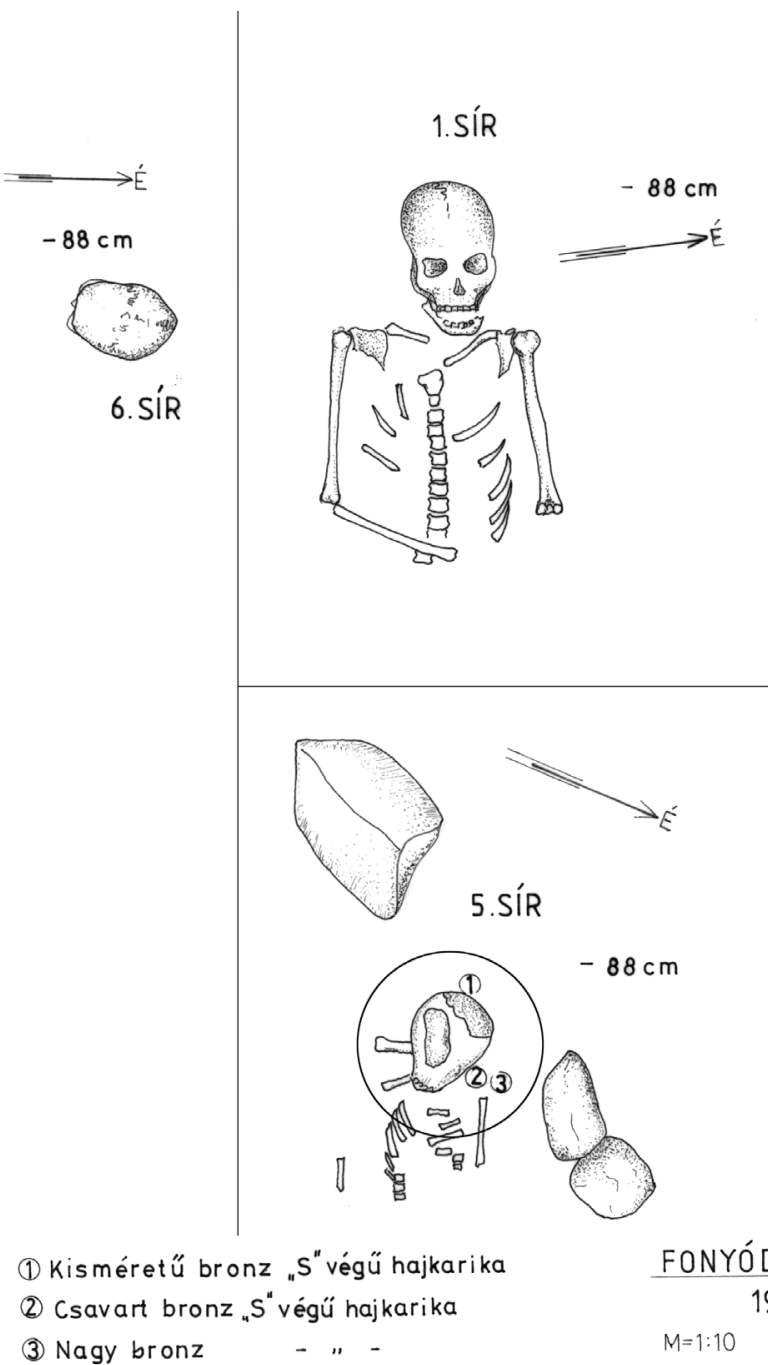

5. sír

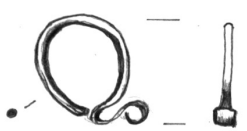

1

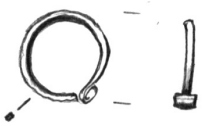

2

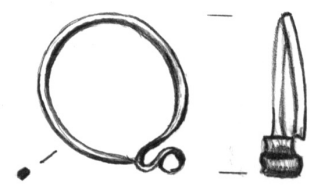

3

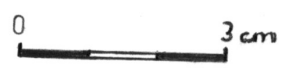

(3) Nagy bronz feltárásból (M. Hrotkó Zsuzsanna) 

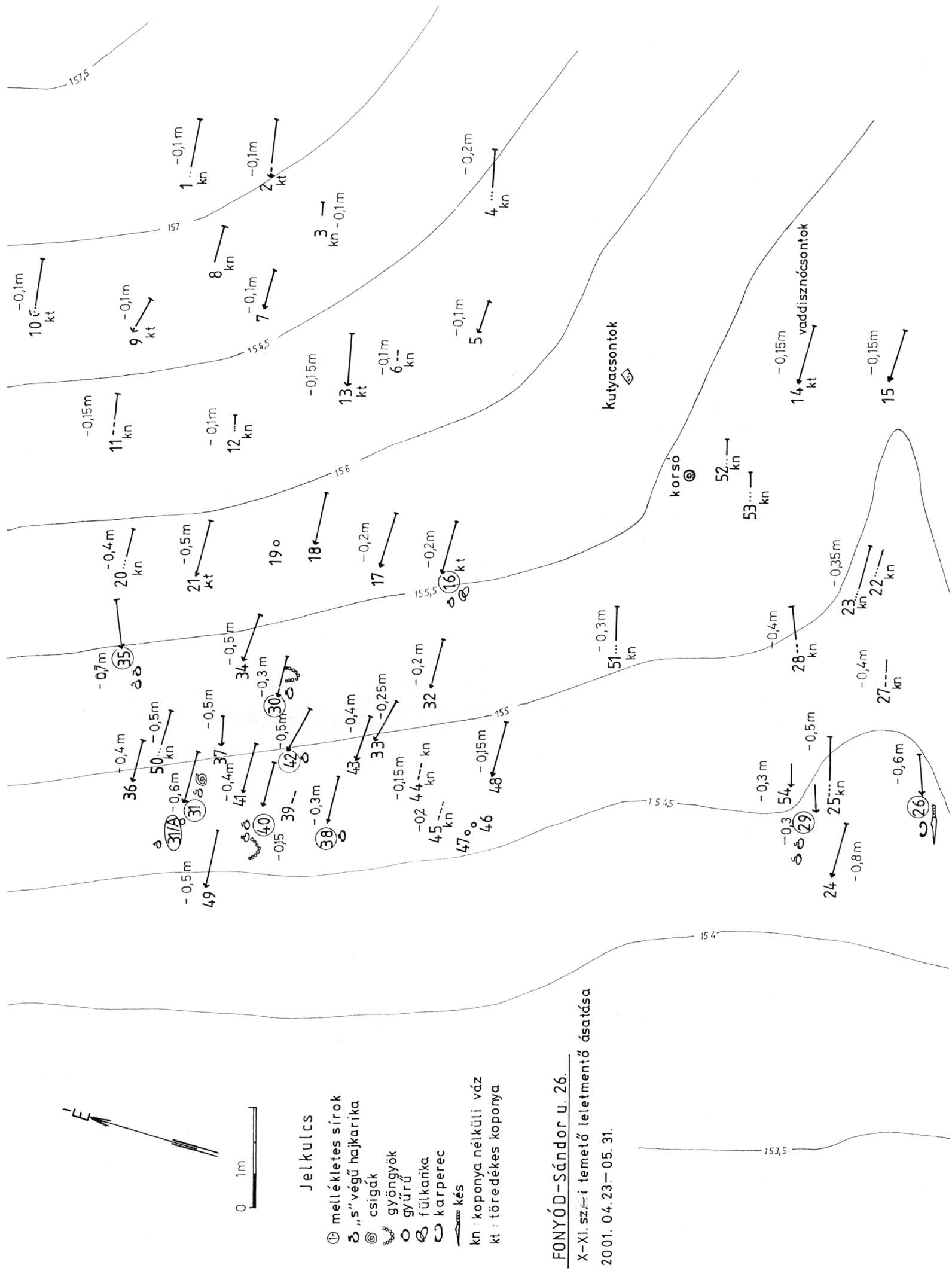

9. ábra. A Sándor utca 26. számú telken 2001-ben feltárt 10-11.századi temető 1-54. sírja a rétegszintvonalas térképen (Geototh, Marcali) 


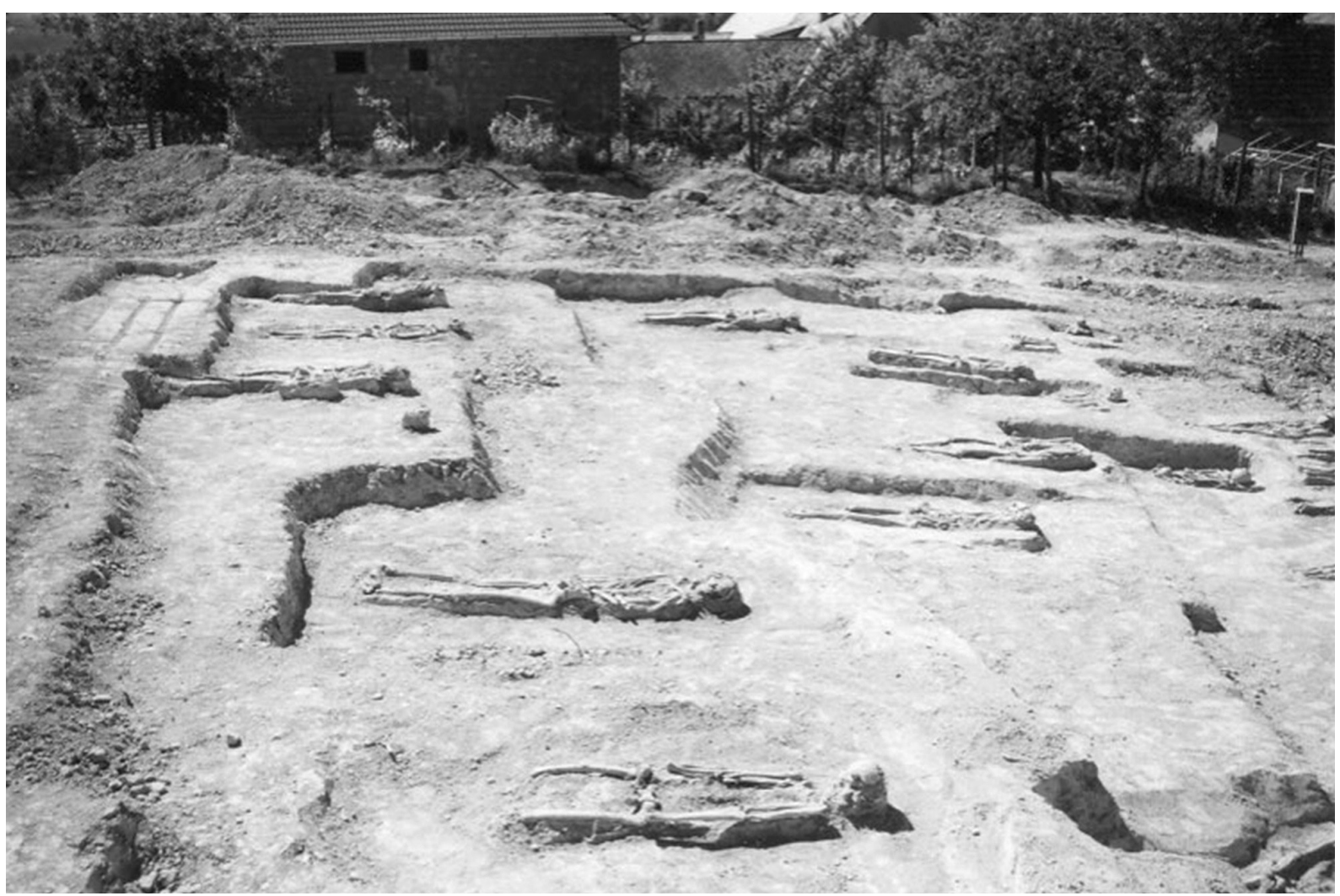

10. ábra. Sándor utcai 10-11. századi temető sírjai É-i irányból (Fotó: Dr. Magyar Kálmán)

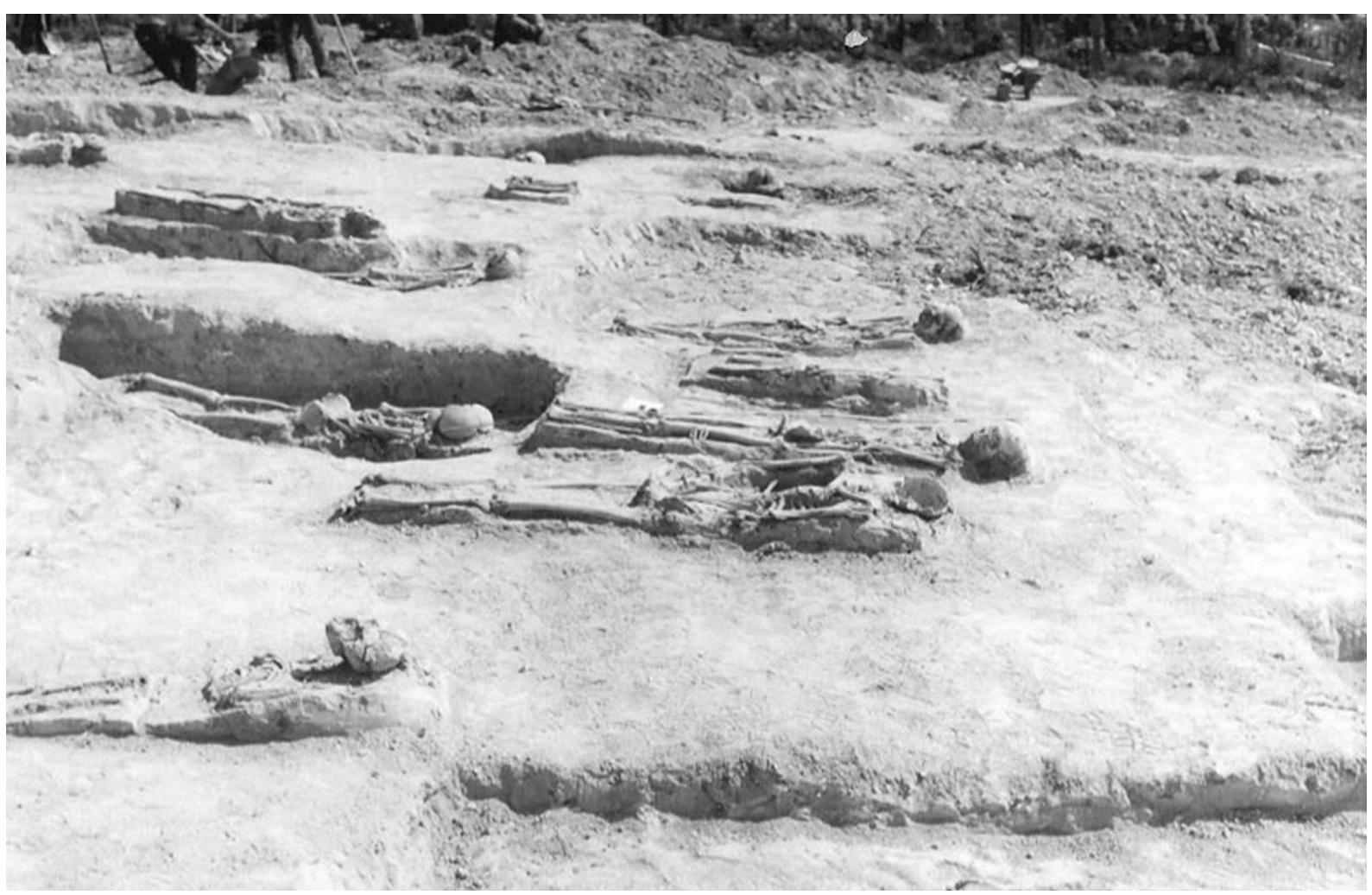

11. ábra. Részletfotó a sírokról (Fotó: Dr. Magyar Kálmán) 

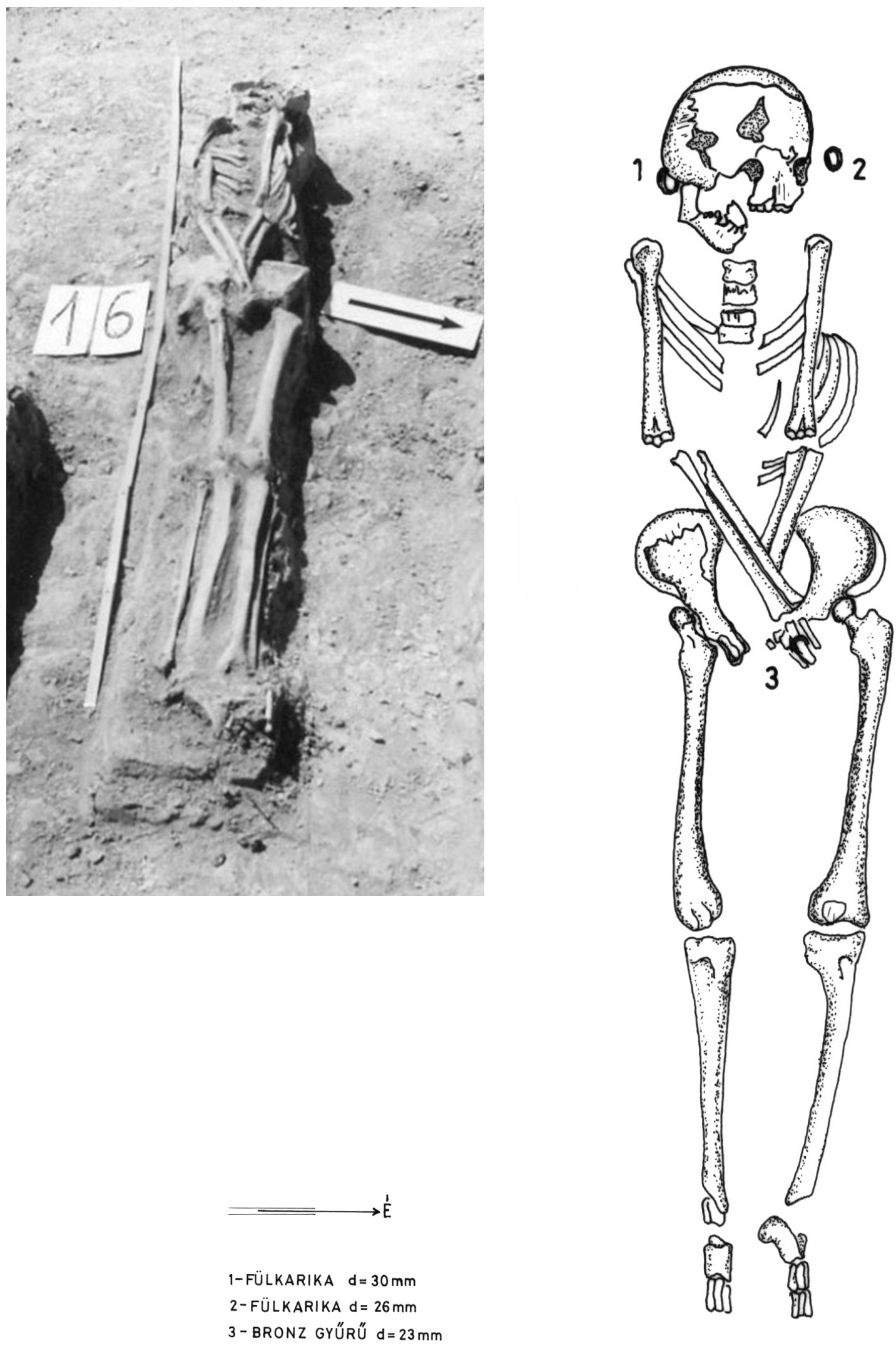

12. ábra. 16. számú mellékletes sír fotója és rajza (M. Hrotkó Zsuzsanna) 

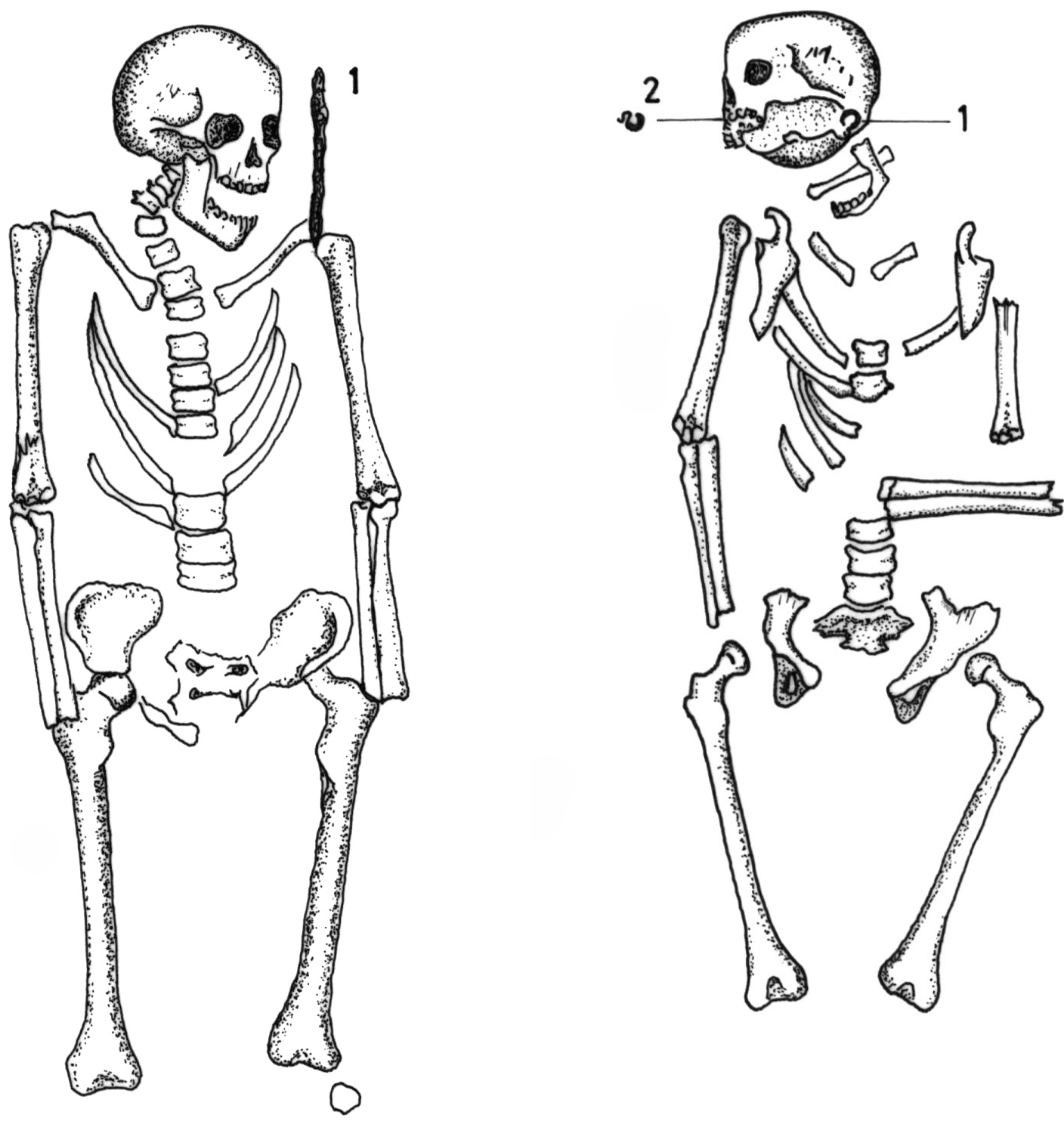

1 VASKÉS $18 \mathrm{~cm} \times 1,3 \mathrm{~cm}$

2 BRONZ KARPEREC

A SIR FELETTI FÖLDBŐL

1-2: BRONZ "S" VÉGÜ

HAJK ARIKÁK
13. ábra. 26. számú mellékletes sír rajza (M. Hrotkó Zsuzsanna)
14. ábra. 29. számú mellékletes sír rajza (M. Hrotkó Zsuzsanna) 

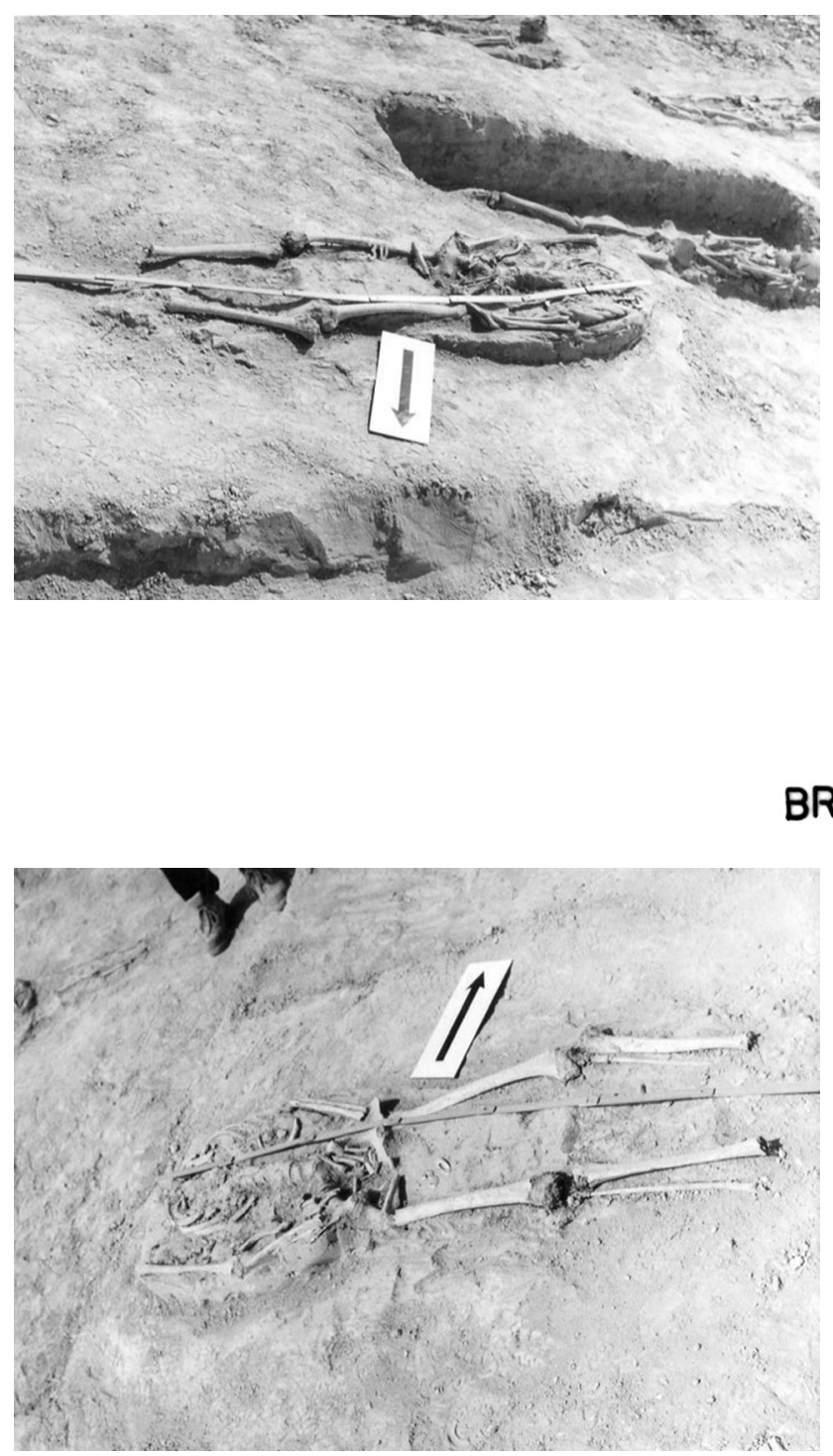

BRONZ

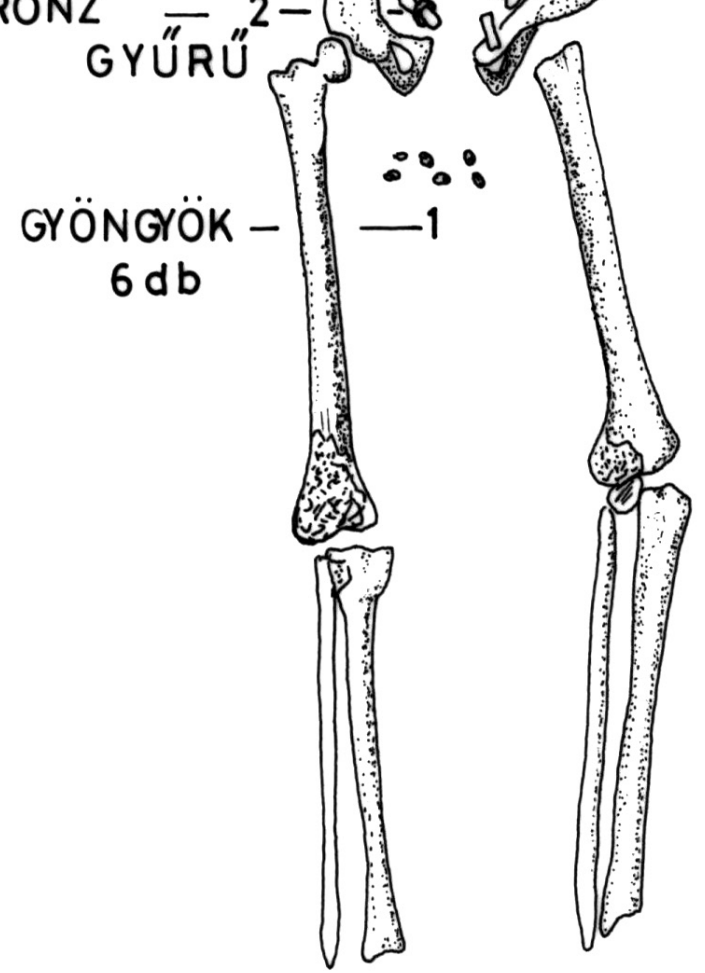



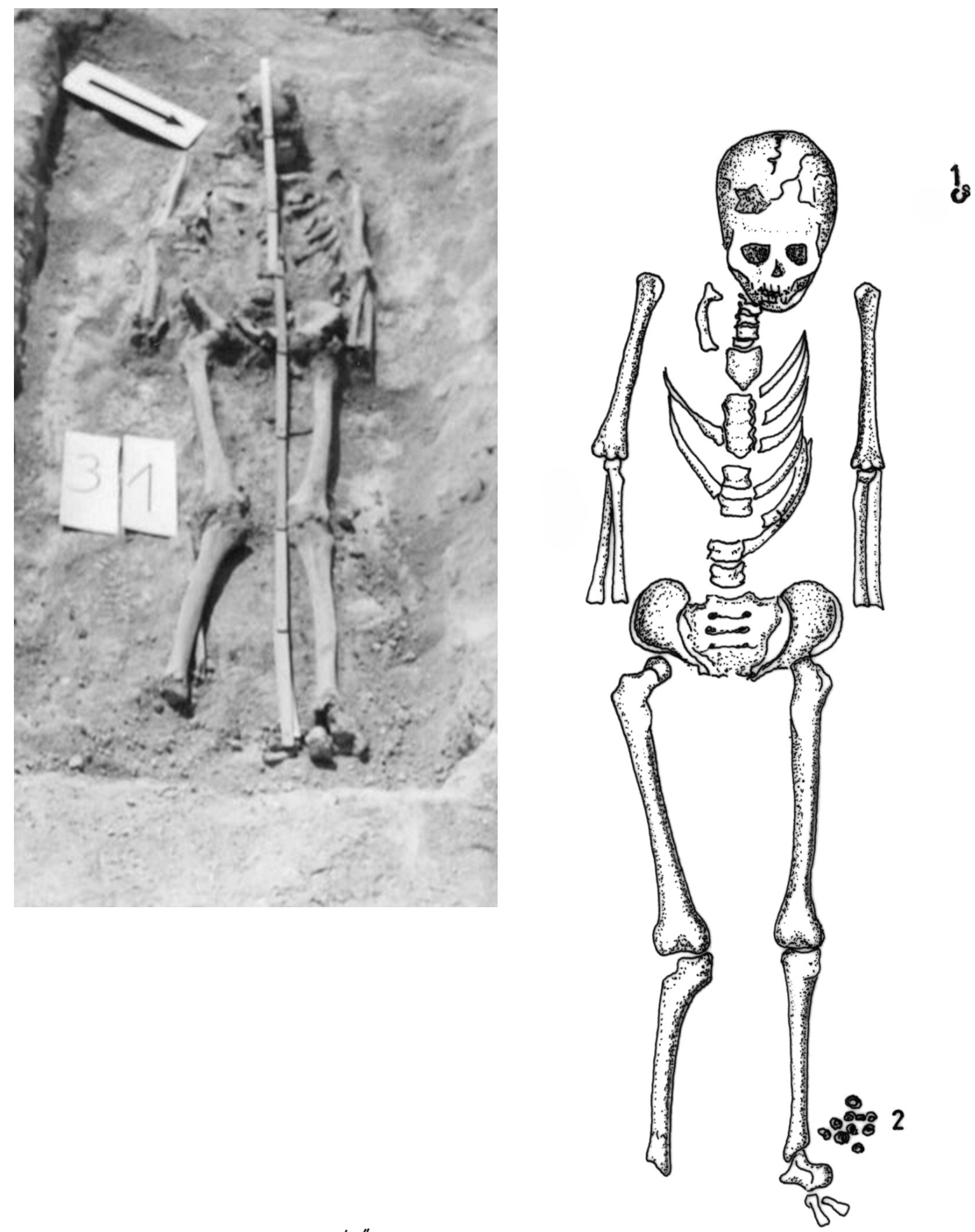

1 - „S"VÉGÜ HAJKARIKA

(bolygatott földböl)

2 - CSIGAHÁZAK $18 \mathrm{db}$

16. ábra. 31. számú mellékletes sír fotója és rajza (M. Hrotkó Zsuzsanna) 

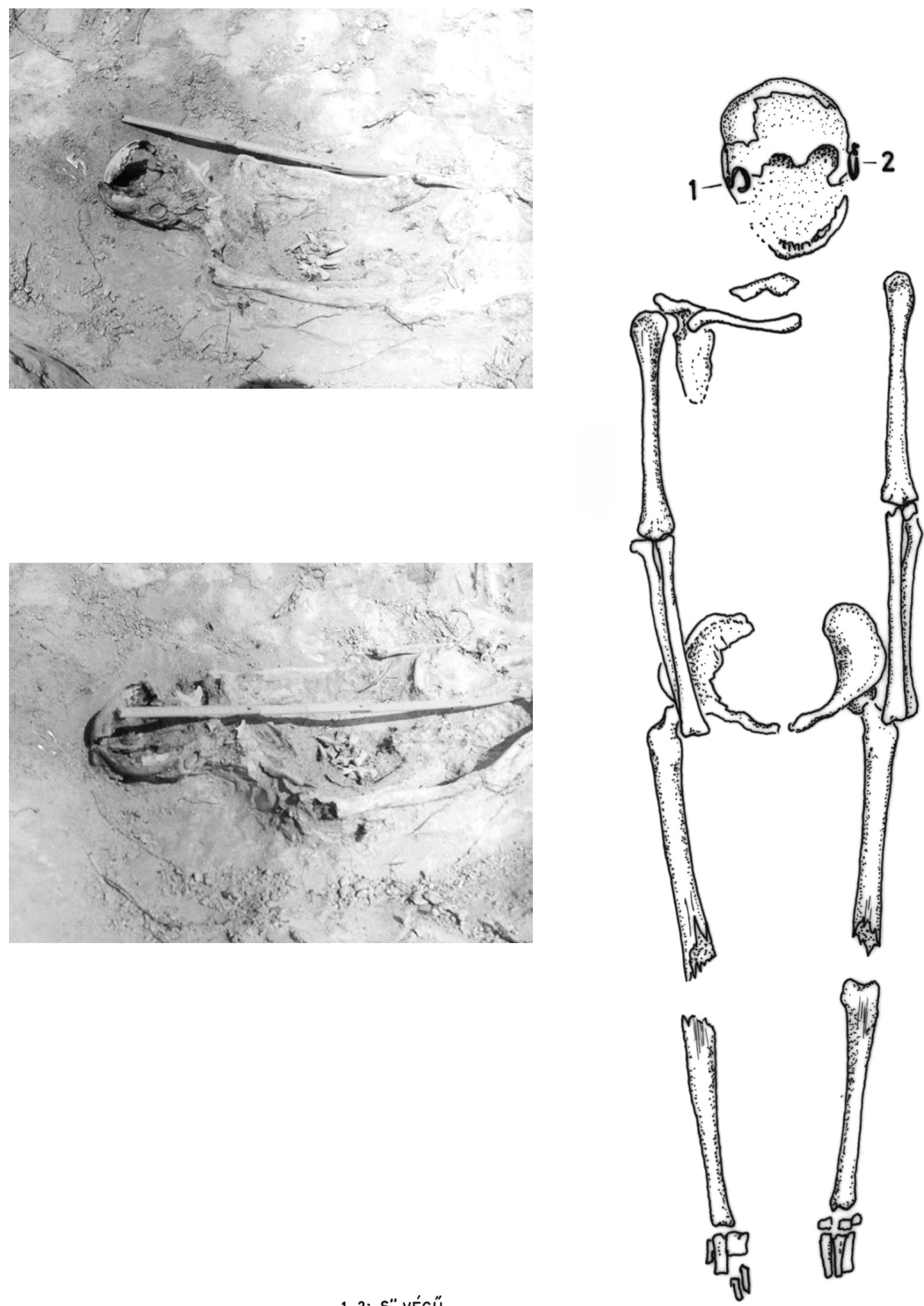

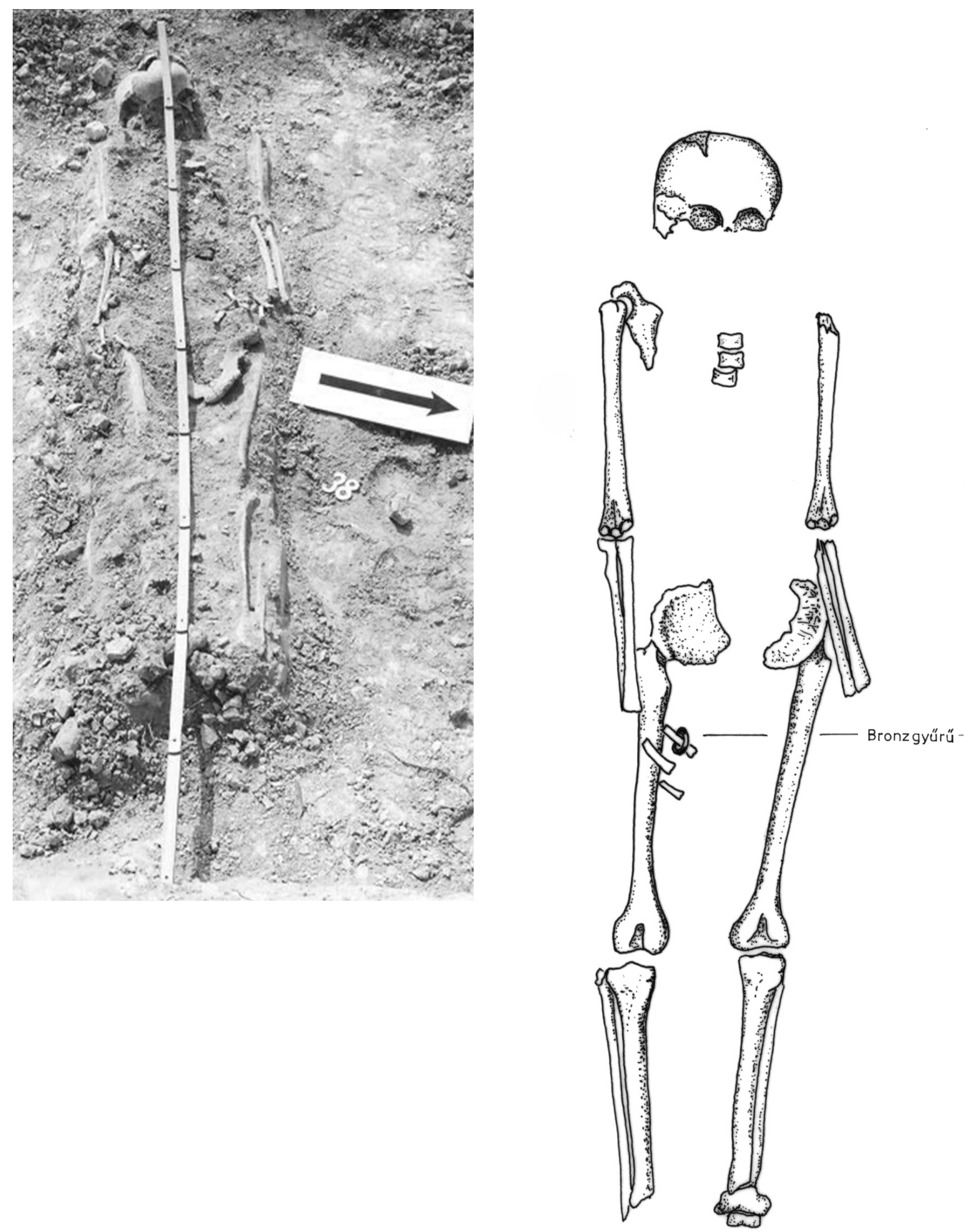

18. ábra. 38. számú mellékletes sír fotója és rajza (M. Hrotkó Zsuzsanna) 

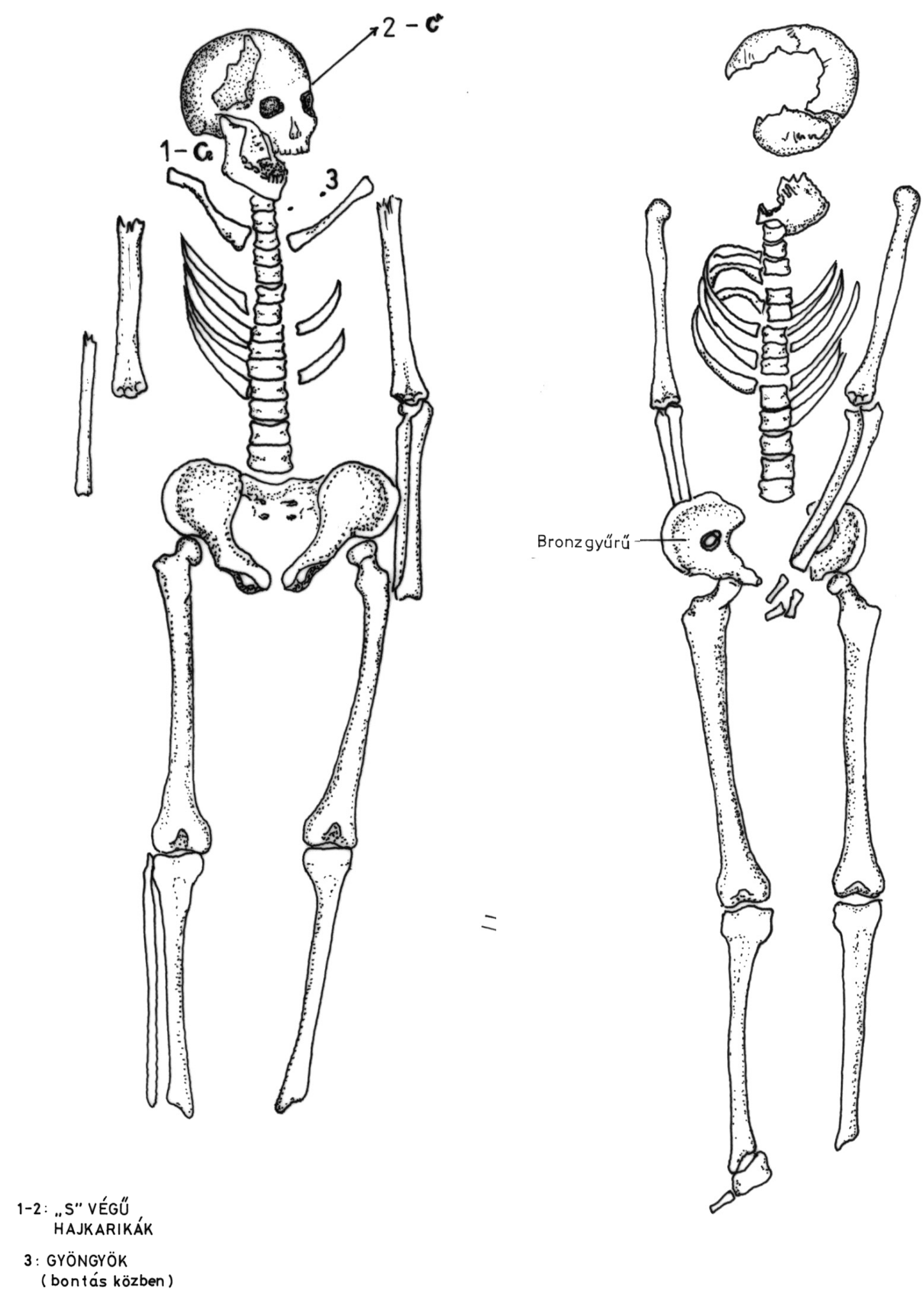

3: GYÖNGYÖK 

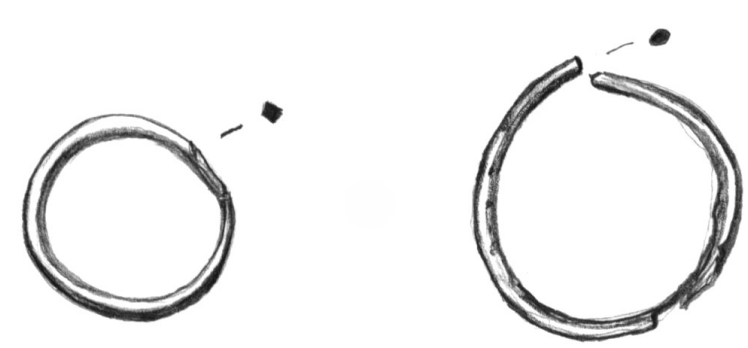

16.sír

1

2

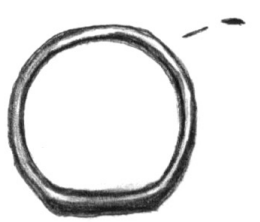

3
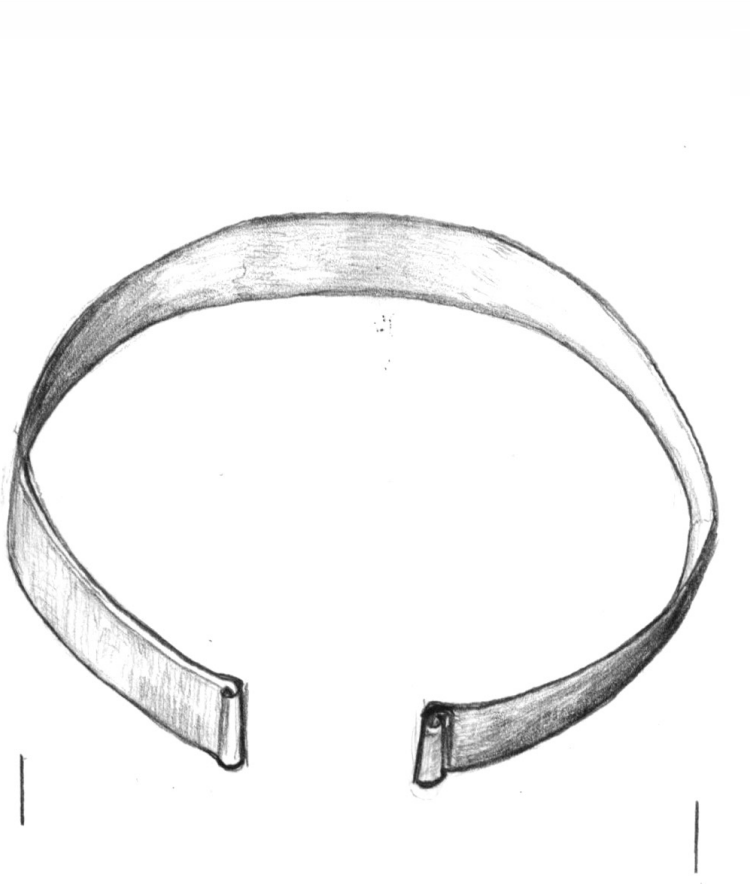

2
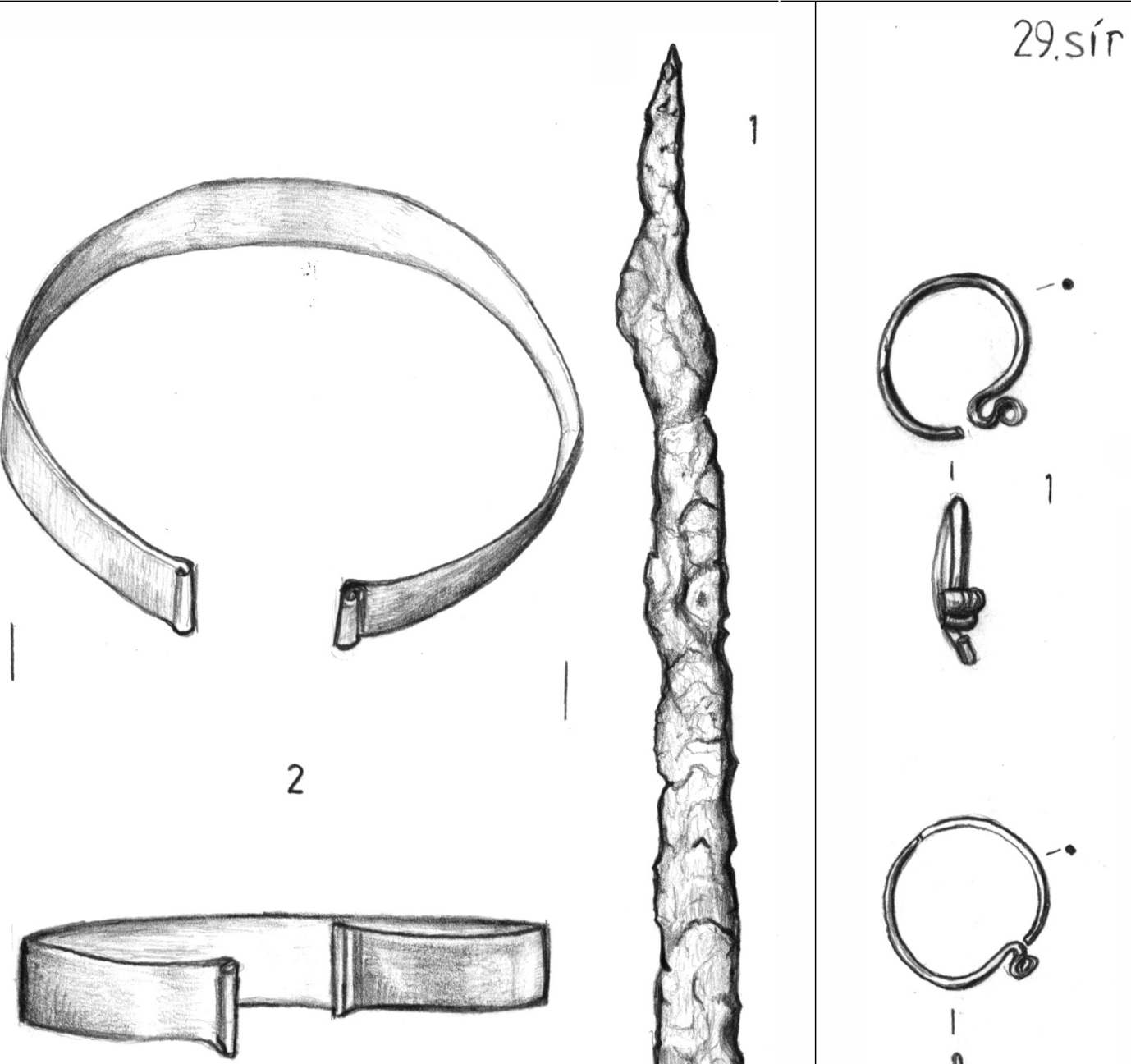

26 sír
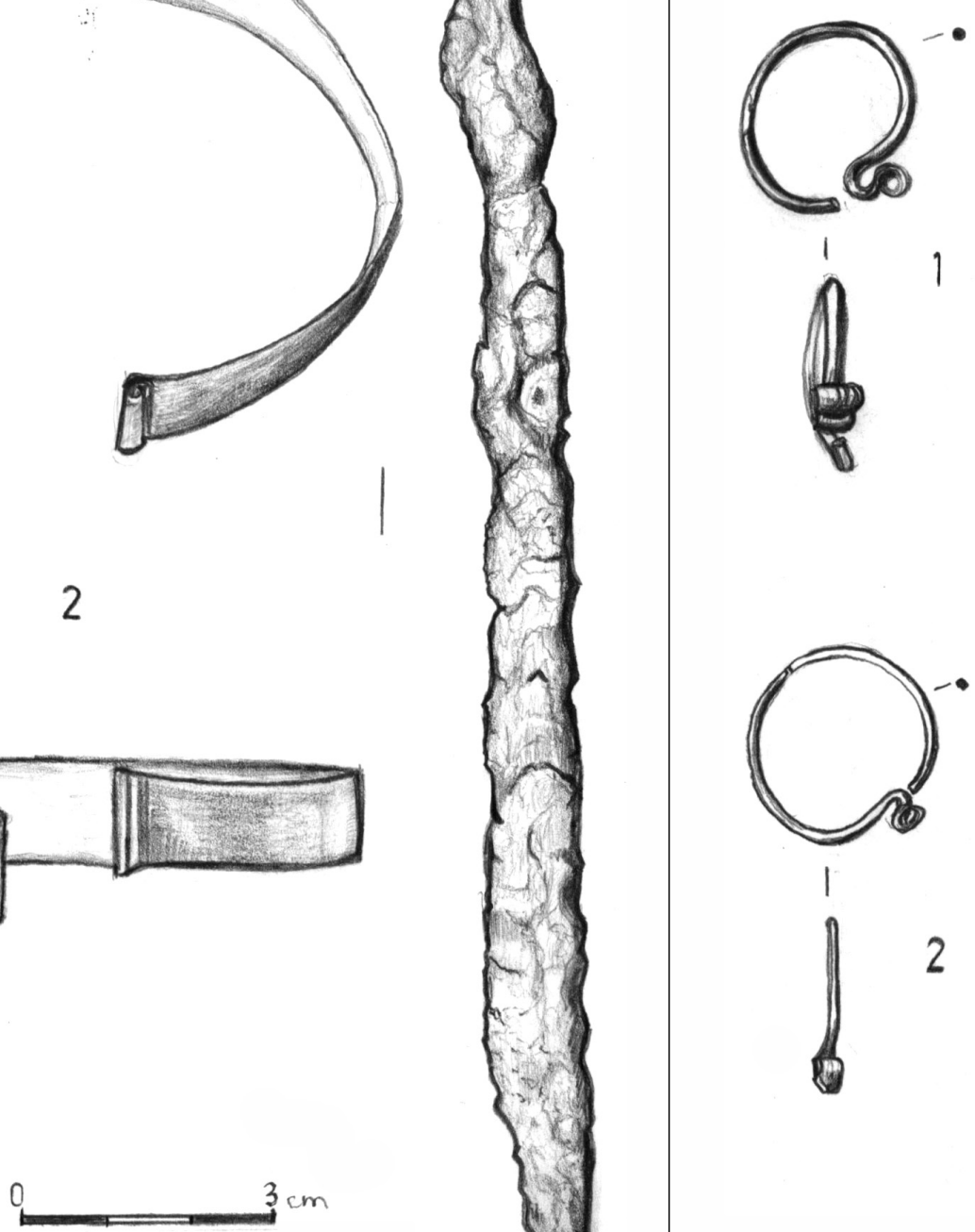

2

21-22. ábra. Fonyód, Sándor utca, 10-11. századi temető 16., 26., 29.számú sírok mellékletei (M. Hrotkó Zsuzsanna) 

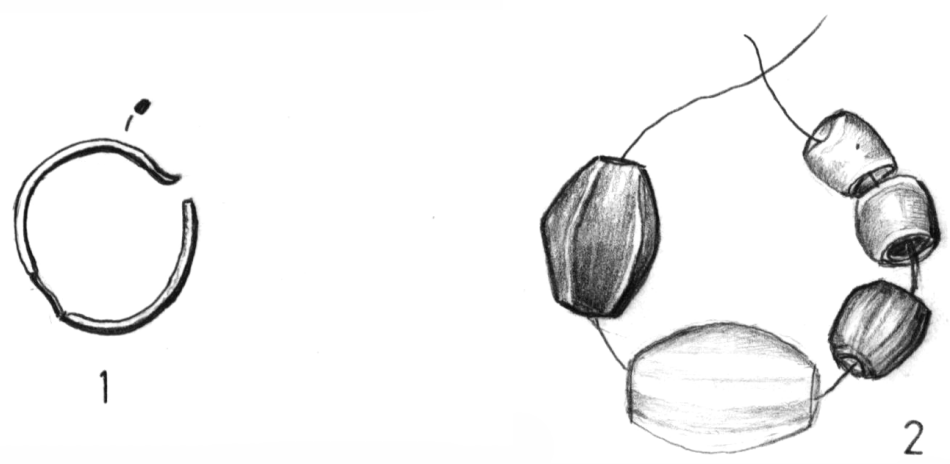

\section{0.sír}

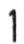

2
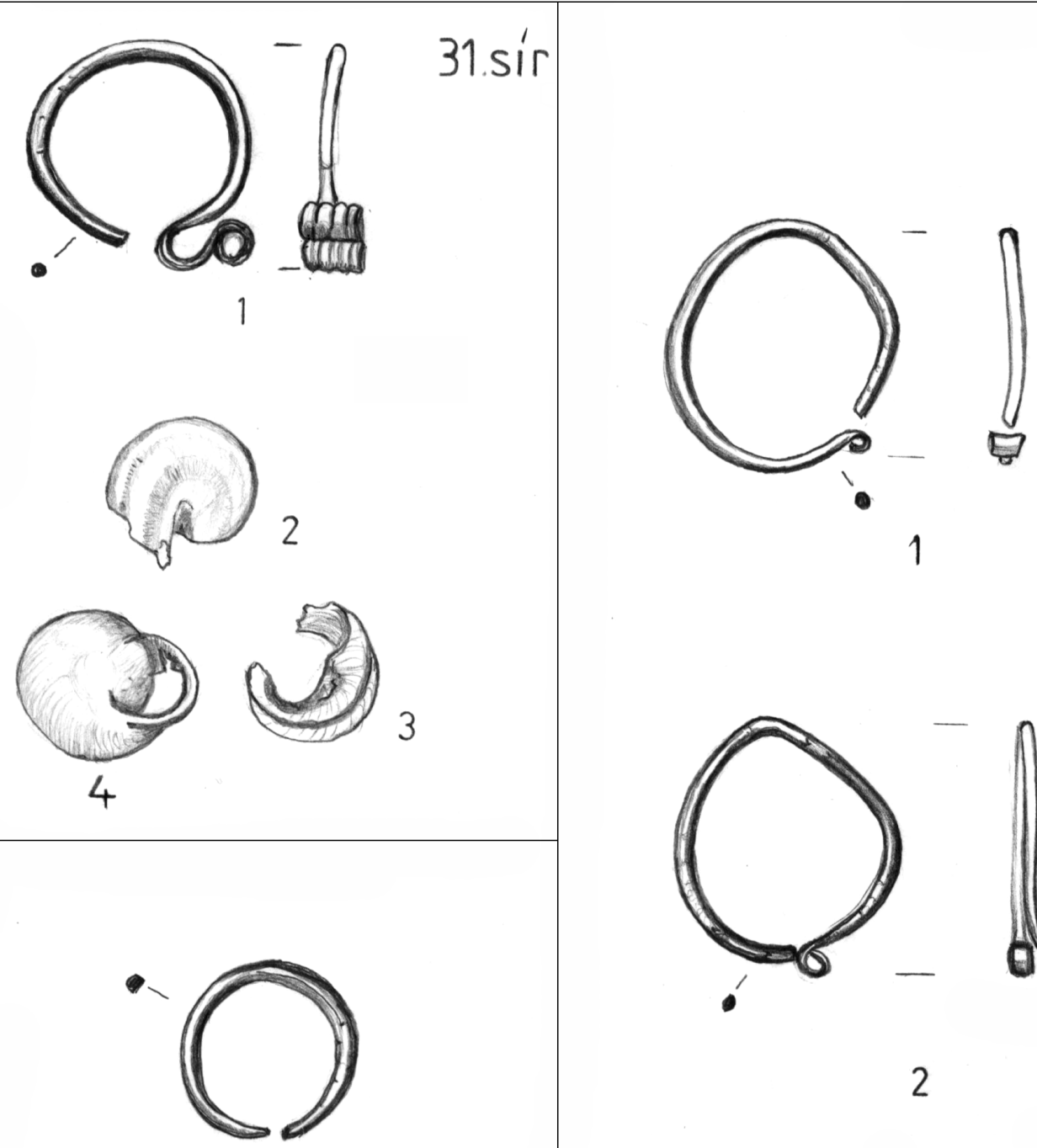

3

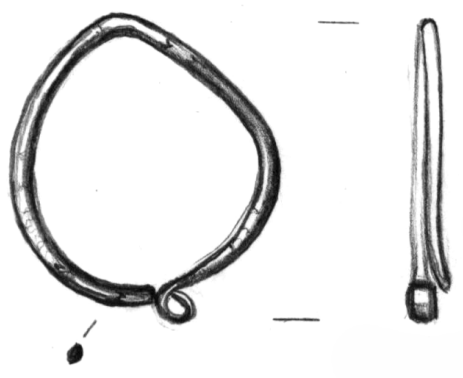

2

1

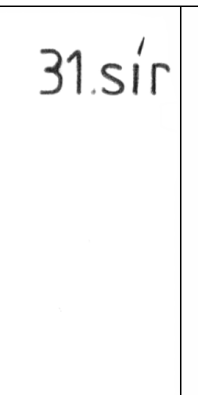




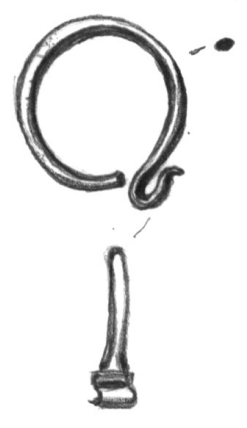

1

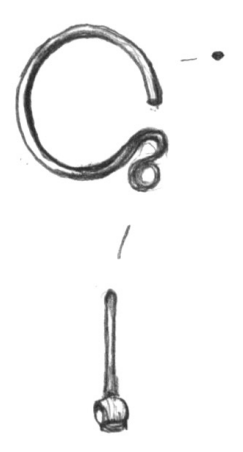

2
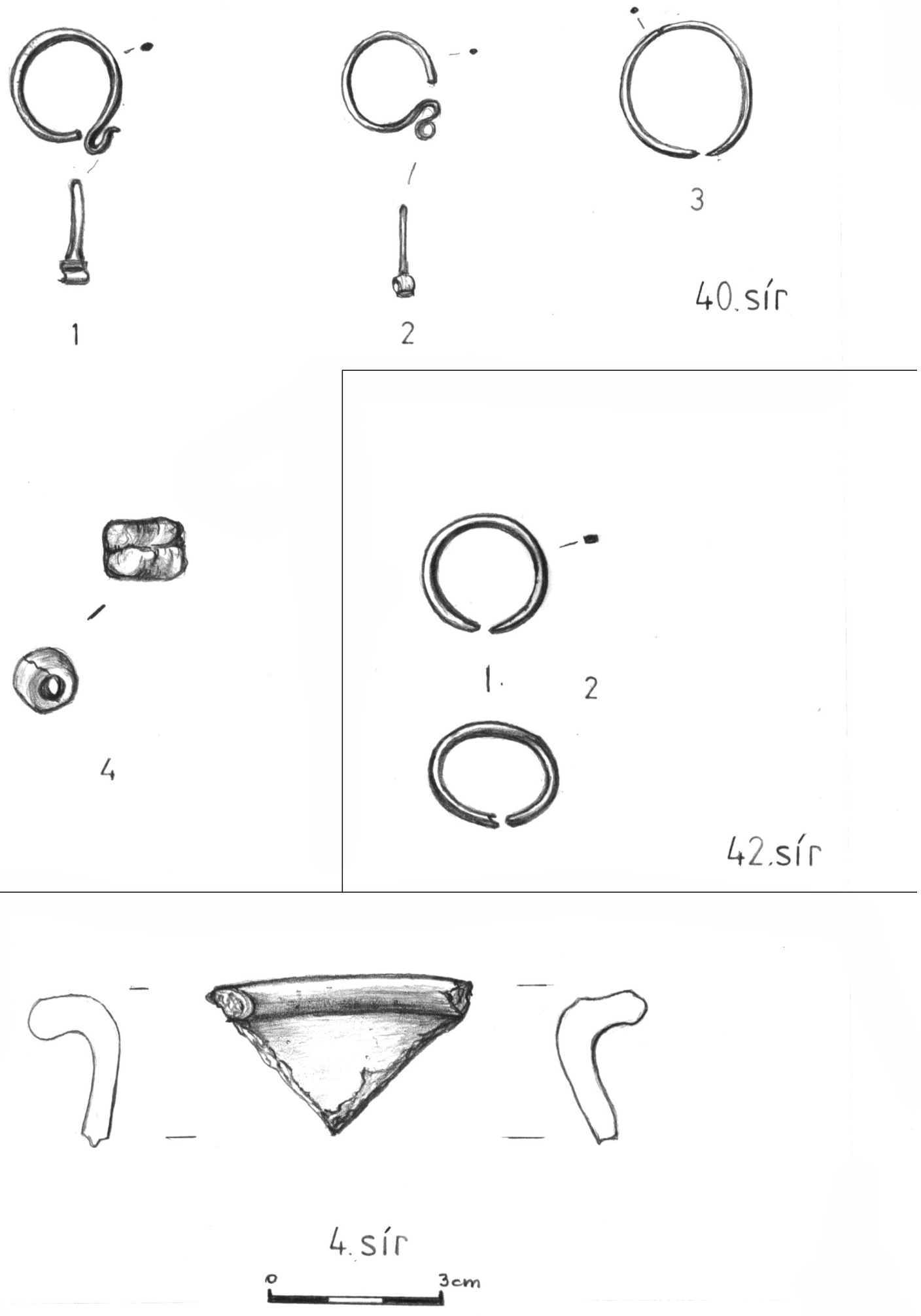

25-26. ábra. Fonyód, Sándor utca, 10-11. századi temető 40., 42., 4. sírok leletei (M. Hrotkó Zsuzsanna) 

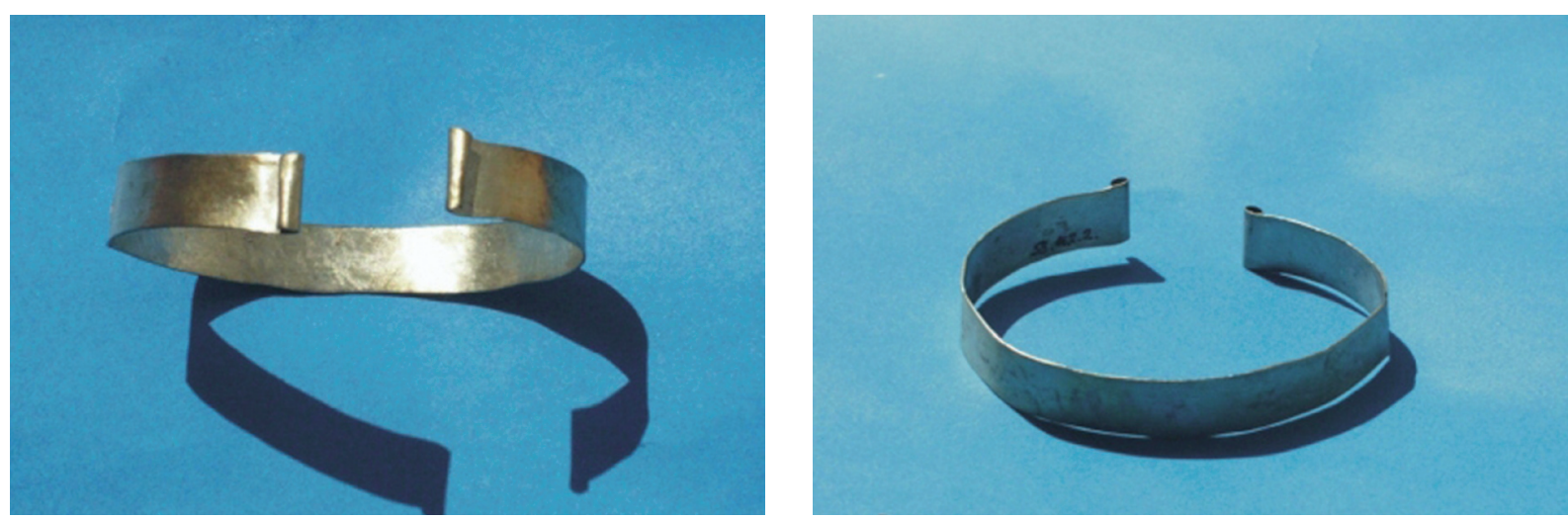

27. ábra. Részletfotók a 26. sír bronz karperecéröl

(M. Hrotkó Zsuzsanna)
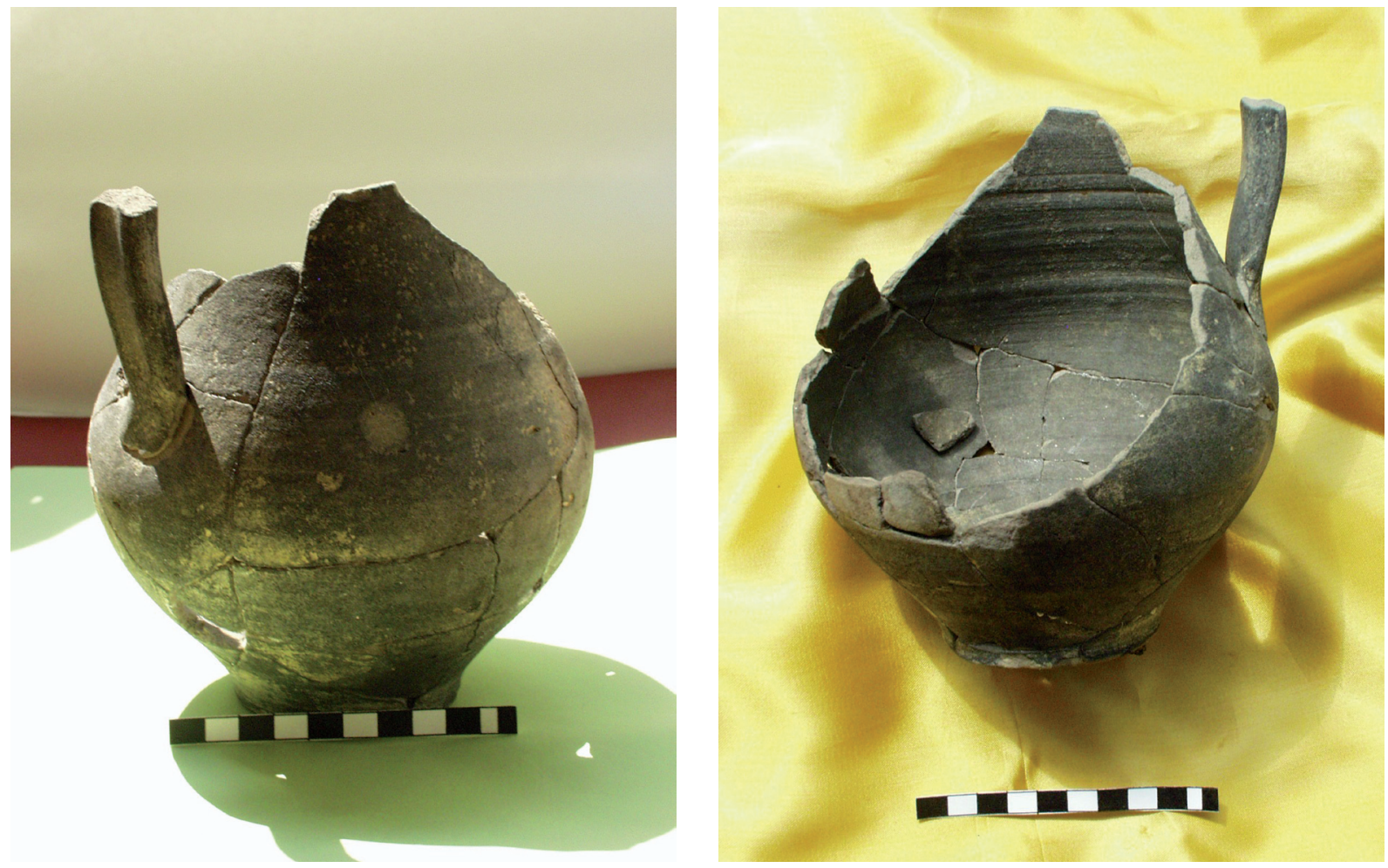

28-29. ábra. Részletfotók a szürkésbarna, törött korsóról

(M. Hrotkó Zsuzsanna) 
